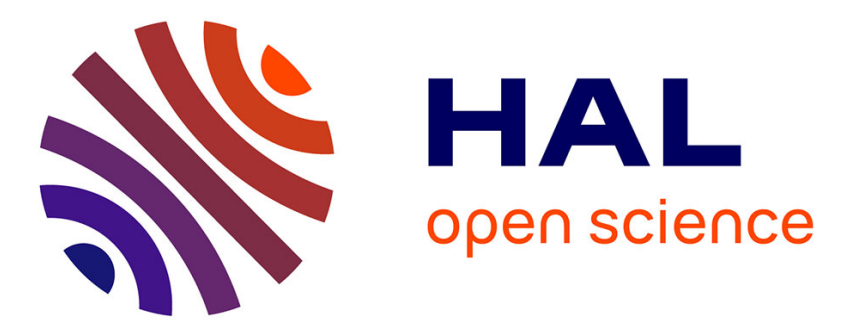

\title{
The transporter CefM involved in translocation of biosynthetic intermediates is essential for cephalosporin production
}

\author{
Fernando Teijeira, Ricardo V. Ullán, Susana M. Guerra, Carlos \\ García-Estrada, Inmaculada Vaca, Juan F. Martín
}

\section{To cite this version:}

Fernando Teijeira, Ricardo V. Ullán, Susana M. Guerra, Carlos García-Estrada, Inmaculada Vaca, et al.. The transporter CefM involved in translocation of biosynthetic intermediates is essential for cephalosporin production. Biochemical Journal, 2009, 418 (1), pp.113-124. 10.1042/BJ20081180 . hal-00479045

\section{HAL Id: hal-00479045 \\ https://hal.science/hal-00479045}

Submitted on 30 Apr 2010

HAL is a multi-disciplinary open access archive for the deposit and dissemination of scientific research documents, whether they are published or not. The documents may come from teaching and research institutions in France or abroad, or from public or private research centers.
L'archive ouverte pluridisciplinaire HAL, est destinée au dépôt et à la diffusion de documents scientifiques de niveau recherche, publiés ou non, émanant des établissements d'enseignement et de recherche français ou étrangers, des laboratoires publics ou privés. 


\section{The transporter CefM involved in translocation of biosynthetic intermediates is essential for cephalosporin production}

*) Instituto de Biotecnología de León (INBIOTEC). Parque Científico de León, Av. Real, 1, 24006, León, Spain.

$\dagger)$ Área de Microbiología, Departamento de Biología Molecular, Facultad de CC. Biológicas y Ambientales, Universidad de León, Campus de Vegazana s/n. 24071, León, Spain.

30 Corresponding author: Dr. Juan Francisco Martín. Área de Microbiología, Departamento de Biología Molecular, Facultad de CC. Biológicas y Ambientales, Universidad de León, Campus de Vegazana s/n. 24071, León, Spain. Phone: +34 987 291505; Fax: +34 987 291506. E-mail: jf.martin@unileon.es

Fernando Teijeira ${ }^{\dagger}$, Ricardo V. Ullán ${ }^{*}$, Susana M. Guerra , Carlos García-Estrada ${ }^{*}$, Inmaculada Vaca*, Juan F. Martín ${ }^{*}$, .

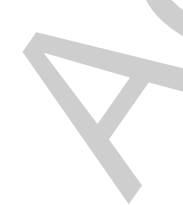

SHORT TITLE: CefM transporter is essential for cephalosporin biosynthesis 


\section{SYNOPSIS}

50 The cluster of early cephalosporin biosynthesis genes ( $p c b A B, p c b C$, cefD1, cefD2 and cefT of Acremonium chrysogenum) contains all genes required for the biosynthesis of the cephalosporin biosynthetic pathway intermediate penicillin N. Downstream of the cefDl gene there is an unassigned open reading frame named cef $M$ encoding a protein of the MFS family with 12 transmembrane spanning domains, different from the previously reported cef $T$. Targeted inactivation of cef $M$ by gene replacement showed that it is essential for cephalosporin biosynthesis. The disrupted mutant accumulates a significant amount of penicillin $\mathrm{N}$, is unable to synthesize deacetoxy-, deacetylcephalosporin $\mathrm{C}$ and cephalosporin $\mathrm{C}$ and shows impaired differentiation into arthrospores. Complementation of the disrupted mutant with the cef $M$ gene restored the intracellular penicillin $\mathrm{N}$ concentration to normal levels and allowed synthesis and secretion of the cephalosporin intermediates and cephalosporin C. A fused cefM-gfp gene complemented the cefM-disrupted mutant and the CefM-GFP protein was targeted to intracellular microbodies that were abundant after $72 \mathrm{~h}$ of culture in the differentiating hyphae and in the arthrospore chains, coinciding with the phase of intense cephalosporin biosynthesis. Since the dual component enzyme system CefD1CefD2 that converts isopenicillin $\mathrm{N}$ to penicillin $\mathrm{N}$ contains peroxisomal targeting sequences, is probably that the epimerization step takes place in the peroxisome matrix. The CefM protein seems to be involved in the translocation of penicillin $\mathrm{N}$ from the peroxisome (or peroxisome-like microbodies) lumen to the cytosol where it is converted to cephalosporin $\mathrm{C}$.

Keywords: Acremonium chrysogenum, cephalosporin C biosynthesis, CefM transporter, translocation of penicillin $\mathrm{N}$ from microbodies, compartmentalization.

Abbreviations used:

CCM, complex culture medium; CPC, cephalosporin C; DAC, deacetylcephalosporin C; DP, Shen's defined production medium; DTT, dithiothreitol; GFP, Green fluorescent protein; HPLC, high performance liquid chromatography; IPN, isopenicillin N; ORF, open reading frame; PenN, penicillin N; Pex19, peroxisome biogenesis factor 19; PTS1, peroxisomal targeting signal 1; PTS2, peroxisomal targeting signal 2; RT-PCR, reverse transcription-polymerase chain reaction. 


\section{INTRODUCTION}

90

Industrial production of cephalosporins is performed with the filamentous fungus Acremonium chrysogenum [1,2], although the ability to produce cephalosporin is also present in other fungi [3] including Kallicrhoma tethys, a marine fungus in which some genes for cephalosporin biosynthesis have been reported recently.

The genes involved in cephalosporin $\mathrm{C}$ biosynthesis in $A$. chrysogenum are arranged in two separate clusters i) the 'early' cephalosporin cluster that includes the genes involved in the four initial steps of the biosynthetic pathway [ $p c b A B$ encoding ACV synthetase, $p c b C$ (isopenicillin $\mathrm{N}$ synthase), cefD1 (isopenicillinyl-CoA synthethase), cefD2 (isopenicillinyl-CoA epimerase)] located in chromosome VII (4.6 Mb) and ii) a 'late' cephalosporin cluster [cefEF encoding deacetoxicephalosporin $\mathrm{C}$ synthase (expandase) /deacetylcephalosporin $\mathrm{C}$ hydroxylase, cefG (acetyl-coenzyme A: deacetylcephalosporin $\mathrm{C}$ acetyltransferase)] in chromosome I (2.2 Mb) [4-7].

This arrangement of the cephalosporin genes in two separate clusters is intriguing and contrast with the organization in Penicillium chrysogenum where all the genes ( $p c b A B$, $p c b C$ and $p e n D E$ ) of the penicillin pathway are clustered in a single $17 \mathrm{~kb}$ DNA region [8] located in chromosome I $(10.4 \mathrm{Mb})$ [9]. These observations suggest that the cephalosporin pathway has been evolutively assembled from two different parts encoded by separate DNA fragments [10].

In Penicillium chrysogenum some specific steps of the $\beta$-lactam biosynthesis pathway are compartmentalized within fungal cells; the first two steps (formation of the ACV tripeptide and its cyclyzation to isopenicillin N) occur in the cytosol [11,12], whereas the last steps (activation of phenylacetic acid to phenylacetyl-CoA and the conversion of isopenicillin $\mathrm{N}$ to benzylpenicillin) occur in peroxisomes [13,14].

In $A$. chrysogenum, it was initially believed that all steps have a cytosolic location $[11,12]$. However, recent evidence suggests that the epimerization of isopenicillin $\mathrm{N}$ (IPN) to penicillin N (PenN) is catalyzed by peroxisomal enzymes (R. V. Ullán, I. Vaca, F. Teijeira and J. F. Martín, unpublished work). This compartmentalization requires specific membrane transport steps across the peroxisomal membranes. Nothing is known about peroxisomal transporters in these fungi. The cefT [15] and atrD [16] encoded transporters appear to be related to secretion of $\beta$-lactam antibiotics out of the cells.

In $A$. chrysogenum the previously reported cefT gene [15] is located in the early cephalosporin cluster (chromosome VII) downstream from $p c b A B$ and encodes a multidrug efflux pump protein belonging to the Major Faciltator Superfamily (MFS) of membrane proteins. The CefT protein confers resistance to some toxic organic acids including isovaleric acid and phenylacetic acid. Overexpression of the cefT gene in $A$. chrysogenum resulted in a two-fold increase in cephalosporin $\mathrm{C}$ production. Nevertheless, targeted inactivation of cefT with the double marker technique [17] revealed that cefT is not essential for cephalosporin biosynthesis $[7,15]$ and suggested the presence of redundant systems involved in cephalosporin secretion.

In order to search for proteins involved in cephalosporin secretion, we have characterized the genes in the region located downstream of the cefDl gene (distal to $c e f T$ ) in the early cephalosporin gene cluster of $A$. chrysogenum. In this article, we report the characterization of a new gene cef $M$ that encodes a membrane protein belonging to the MFS family and its essential role in $\beta$-lactam transport.

The microbodies are single membrane bound organelles that contribute to the $\alpha$ - and $\beta$ oxidation of fatty acids, bile acids, colesterol and several other toxic compounds. A class of microbodies has been identified as peroxisomes [18]. The mechanism of import 
of peroxisomal matrix proteins has been partially elucidated [reviewed by 19]. There are 140 several types of peroxisomal targeting sequences: for matrix proteins (PTS-1 and PTS2) [19] and for membrane proteins [20,21]. These targeting sequences of peroxisomal membrane proteins, contain a basic amino acid combined with at least one transmembrane region [22-24]. These proteins are recruited from the cytoplasm by the Pex 19p [25] and the consensus sequences for binding to Pex19p have been identified 145 [26].

It was therefore of interest to study if the MDR transmembrane proteins encoded by genes located in the 'early' cephalosporin cluster are targeted to the peroxisomal membrane. We described in this article for the first time, the compartmentalization in microbodies of one part of the cephalosporin $\mathrm{C}$ biosynthesis pathway.

\section{EXPERIMENTAL}

\section{Microorganism and culture media}

Acremonium chrysogenum C10 (ATCC 48272) a high-cephalosporin-producing strain available from PanLabs was used in this study. For sporulation A. chrysogenum C10 and the mutant strains were grown in solid LPE medium [7,15] for 7 days at $28{ }^{\circ} \mathrm{C}$.

160 Spores and mycelium fragments collected from six plates of LPE medium were suspended in $100 \mathrm{ml}$ of seed medium [7] in $500 \mathrm{ml}$ shake-flasks and incubated at $25{ }^{\circ} \mathrm{C}$ for $48 \mathrm{~h}$ in an orbital incubator at $250 \mathrm{rpm}$. Ten $\mathrm{ml}$ of seed culture was used to inoculate $100 \mathrm{ml}$ of Shen's defined production (DP) medium. The cultures were incubated in triple-baffled flasks $\left(500 \mathrm{ml}\right.$; Bellco) containing $100 \mathrm{ml}$ of medium at $25^{\circ} \mathrm{C}$ in a rotary

165 shaker $(250 \mathrm{rpm})$. Samples were taken every $24 \mathrm{~h}$, and cephalosporin production was determined by bioassays against Escherichia coli ESS2231 as the test strain in plates with penicillinase (from Bacillus cereus UL1) as described previously [27]. For confocal laser scanning microscopy studies, the A. chrysogenum strains were grown in CCM medium.

\section{Library screening}

A gene library of $A$. chrysogenum $\mathrm{C} 10$ was constructed in the ble-EMBL3 vector as described before (4). The E. coli LE392 strain was infected with the phages contained in the gene library of $A$. chrysogenum $\mathrm{C} 10$. The DNA of phages in the lysis plaques of the infection plates was transferred onto Hybond-NX membranes (Amersham-Biosciences). In order to find the positive phages with the new open reading frame, two or three consecutive rounds of hibridations were done using the apropiate digoxigenin labelled probe according the Dig Easy Hyb system (Roche Diagnostic Corporation) as described by Ullán et al. [15]. Finally, the DNA fragment containing the cef $M$ gene was cloned and sequenced.

\section{DNA isolation and Southern blotting}

Genomic DNA of A. chrysogenum was isolated as described previously [7]. Samples of genomic DNAs $(3 \mu \mathrm{g})$ from $A$. chrysogenum $\mathrm{C} 10$ and its transformants were digested with restriction enzymes and separated in $0.7 \%$ agarose gels. The gels were blotted onto Hybond-NX membranes (Amersham-Biosciences) as described by Ullán et al. [15]. For Southern blot analysis the Dig Easy Hyb system (Roche Diagnostic Corporation) was used. Hybridizations were performed according to the manufacturer's protocol and the 
hybridization signals were visualized with chemiluminescence and recorded on X-ray

film with an exposure time of $5 \mathrm{~min}$.

\section{Plasmids containing the cefM gene}

pcefMa and pcefMb. The EcoRV fragment of $3.1 \mathrm{~kb}$ containing the cef $M$ gene under the control of its own promoter was placed in two opposite orientations (a or b) at the unique EcoRV site of pZErO-2 (Invitrogen)

pDM. This plasmid contains a disrupted $c e f M$ gene that was obtained by insertion of the bleomycin resistance (ble) cassette (1.47 kb fragment) from pJL43 [4] into the XhoI site.

200 The hygromycin resistance (hph) cassette, subcloned from pAN7-1 [17], was inserted in the BamHI site.

pCM. This plasmid was used for trans complementation of the cef $M$ disruptant strain. To construct pCM a HindIII-XbaI $3.2 \mathrm{~kb}$ fragment from pcefMa was inserted into the HindIII-XbaI site of pAN7.1.

pcefM-GFP. To obtain the fused cefM-gfp gene an Ecl136II $2.6 \mathrm{~kb}$ DNA-fragment obtained from plasmid pcefMa by PCR using the M13 Forward and MC (5'GAGCTCCCACAGCGCTGGCTGAA-3') oligonucleotides, was inserted into the

210 Ecl136II site of pMCB15 bearing the gfp2.5 gene of Aquarea victoria [28].

\section{DNA sequencing}

Sequencing reactions of the DNA were made by standard procedures [15] and automatic sequencing was performed with the AutoRead ${ }^{\mathrm{TM}}$ System (Pharmacia, Uppsala,

215 Sweden).

\section{RNA extraction and intron analysis}

Total A. chrysogenum RNA was isolated with the RNeasy Kit (Qiagen) as described previously [29]. To elucidate the presence of putative introns in the DNA sequence of the cefM gene (ORF10), the DNA region containing the expected introns splicing sites was amplified by RT-PCR (Promega) using RNA of $A$. chrysogenum $48 \mathrm{~h}$ cultures as template with the primer pairs I1-R: 5'-GCTTTGGAGGCGGCGATAGACA-3' and I1F: 5'-GGCGGGGAGGTTGGGACTGA-3'; I2-R: GTGCGCCCTCAGTCCCAACCT-3' and I2-F: 5'225 TGAGAAGACGACGGCGATGAAGAC-3'. I3-R: 5'-CGCCGTCGTCTTCTCATACCAGTT-3' and I3-F: 5'-CCACGGCAATGAATCCAAGAGTCG-3. The amplified regions were sequenced to confirm the presence of the 3 introns.

\section{A. chrysogenum transformation}

230 Transformation of $A$. chrysogenum protoplasts was performed as described previously [4]. Transformants were selected in tryptic soy agar (TSA, Difco) supplemented with sucrose $(0.30 \mathrm{M} ; 10.3 \%)$ as osmotic stabilizer and phleomycin $(10 \mu \mathrm{g} / \mathrm{ml})$ or hygromycin B $(30 \mu \mathrm{g} / \mathrm{ml})$.

235 HPLC determination of isopenicillin $\mathbf{N}$, penicillin $\mathbf{N}$, deacetylcephalosporin $\mathbf{C}$ and cephalosporin $\mathbf{C}$

The extracellular and intracellular concentrations of isopenicillin $\mathrm{N}$ (IPN), penicillin $\mathrm{N}$ (PenN), deacetylcephalosporin C (DAC) and cephalosporin C (CPC) of A. chrysogenum 
strains were determined in a Waters HPLC System equipped with a 2487 dual 240 absorbance detector, using a 4.6 x $250 \mathrm{~mm}$ RPC18 Lichrospher® 100 column (Merck). The elution system used was as described previously by Ullán et al. [7,27].

\section{Cell extracts and western blotting}

Mycelia samples from the different $A$. chrysogenum strains were centrifuged for $10 \mathrm{~min}$ 245 at 4,400 $\mathrm{x}$ g and washed three times in $0.9 \% \mathrm{NaCl}$. Then, they were resuspended in cold TD buffer (50 mM Tris-HCl pH 8.0, $5 \mathrm{mM}$ DTT and Complete ${ }^{\mathrm{TM}}$ solution for protease inhibition (Roche Applied Science). Disruption of cells was achieved by sonication on ice using six pulses of $20 \mathrm{~s}$ with 60 -s intervals between each pulse. After centrifugation at $4,400 \mathrm{x} \mathrm{g}$ for $10 \mathrm{~min}$ at $4^{\circ} \mathrm{C}$, the insoluble fraction was separated from the

250 supernatant. The pellet including integral membrane proteins was resuspended in TD buffer supplemented with $2 \%$ SDS. The mixture was shaken at $15 \mathrm{rpm}$ for $1 \mathrm{~h}$ at room temperature to solubilize the membrane proteins and centrifuged at $13,000 \mathrm{xg}$ for 15 min. The supernatant was analysed by western blotting, using antibodies against GFP (Roche Diagnostic).

255 Protein extracts were diluted in loading buffer (60 mM Tris- $\mathrm{HCl} \mathrm{pH} 6.8,2 \% \mathrm{SDS}, 100$ $\mathrm{mM}$ DTT, $10 \%$ glycerol and $0.1 \%$ bromophenol blue) and boiled for $5 \mathrm{~min}$. The recombinant GFP protein (Roche Diagnostics Corp., Indianapolis, IN, U.S.A.) was used as control and was subjected to the same treatment than the rest of the samples. Proteins were run in a $12 \%$ acrylamide gel, which were electroblotted onto nitrocellulose filters 260 applying a current of $0.65 \mathrm{~mA} / \mathrm{cm}^{2}$ of gel for $2 \mathrm{~h}$. A protein mixture "Precision Plus Protein All Blue Standards" (Bio-Rad, Hercules, CA, USA) was used as molecular weight markers. Membranes were blocked by incubation in $50 \mathrm{mM}$ Tris- $\mathrm{HCl} \mathrm{pH} \mathrm{8.0,}$ $150 \mathrm{mM} \mathrm{NaCl}, 0.2 \%$ Tween 20 and 5\% nonfat milk powder (w/v) for $2 \mathrm{~h}$ at room temperature. Primary mouse monoclonal anti-GFP antibodies were added to this buffer 265 (1/1000 dilution), and the blot was incubated overnight. Filters were washed thoroughly in $50 \mathrm{mM}$ Tris- $\mathrm{HCl}, \mathrm{pH} 8.0,150 \mathrm{mM} \mathrm{NaCl}, 0.2 \%$ Tween 20 and incubated with the anti-mouse IgG conjugated to alkaline phosphatase (Sigma-Aldrich). The reaction signal was detected using nitro-blue tetrazolium chloride and 5-bromo-4 chloro-3 indolyl-phosphate (Roche Diagnostic) as substrates.

\section{Cephalosporin $\mathbf{C}$ synthesis in cell-free extracts}

Mycelia from $A$. chrysogenum cultures in DP medium were collected at $144 \mathrm{~h}$, washed with $0.9 \% \mathrm{NaCl}$ and disrupted by grinding them in a mortar with liquid nitrogen. Cell extracts were resuspended in TD buffer $\left(50 \mathrm{mM} \mathrm{KH}_{2} \mathrm{PO}_{4} \mathrm{pH} 7.0\right)$ and centrifuged at $14000 \mathrm{rpm}$ for $10 \mathrm{~min}$ at $4^{\circ} \mathrm{C}$. Cell-free extracts $(500 \mu \mathrm{l})$ were incubated at $25^{\circ} \mathrm{C}$ on a shaker at $250 \mathrm{rpm}$ to provide $\mathrm{O}_{2}$ for the oxygen-dependent expandase/hydroxylase reactions. Samples $(100 \mu \mathrm{l})$ were collected at $1 \mathrm{~h}$, and the reaction was stopped by treatment with 1 volume of methanol. The in vitro formation of cephalosporin $\mathrm{C}$ was determined by HPLC. In absence of added PenN this reaction measures the conversion of endogenous PenN (released by disruption of microbodies) into cephalosporin C.

\section{Fluorescence microscopy}

The fluorescence emissions of hyphae and arthrospores were analyzed by confocal laser scanning microscopy using a Laser Confocal Microscope RADIANCE 2000 (BIO-

285 RAD). Green fluorescent protein (GFP) fluorescence was visualized with a number 13 filter $(470 / 20 \mathrm{~nm} ; 505-530 \mathrm{~nm})$.

\section{RESULTS}




\section{Identification of the ORF 10 downstream of the cefD1 gene}

290 Transmembrane proteins, other than CefT, that might be $\beta$-lactam exporters were searched in the DNA regions adjacent to the cephalosporin gene clusters. To extend the cloned cef region of chromosome VII a gene library of the $A$. chrysogenum $\mathrm{C} 10$ strain [4] was screened with a probe internal to the 'early' gene cluster (330 bp SalI-EcoRV fragment of the cefDl gene). Six phage plaques gave positive hybridization with this

295 probe. They corresponded to phages F2, F3, F4, F5, F6 and F8 with six different inserts of $A$. chrysogenum DNA. Sequence analysis of the region downstream of the cefD1 gene (of phage F8) revealed the presence of a new open reading frame named ORF10.

An EcoR $V$ fragment ( $3.1 \mathrm{~kb}$ long) of the region located downstream of the cefDl gene was cloned into the pZEro2 in both orientations, giving rise to plasmids pcefMa and

$300 \mathrm{pcefMb}$. The inserts pcefMa and pcefMb were completely sequenced on both strands. The nucleotide sequence of this fragment was deposited in the EMBL database under the accession number AM231815 (cefM). Analysis of the nucleotide sequence of the 3.1 $\mathrm{kb}$ DNA insert revealed the presence of one complete ORF, initially named ORF10. This ORF was $1620 \mathrm{nt}$ long and was interrupted by the presence of three introns. The

305 presence of the introns was confirmed by RT-PCR as indicated in Experimental Procedures.

\section{ORF10 encodes a protein with high similarity to multidrug effux pump proteins}

The ORF10 encoded a protein of 482 amino acids with a deduced molecular mass of $31052.2 \mathrm{kDa}$. The amino acid sequence of the ORF10p showed strong similarity throughout its entire length to multidrug efflux pump membrane proteins belonging to the Major Facilitator Superfamily (MFS). The amino acid sequence of the ORF10p showed motifs A, B, C, D2 and G characteristic of the Drug: H+ antiporter 12-TMS group of the major facilitator superfamily [30]. This protein is similar to MFS proteins (Fig. 1) of 315 Neosartorya fischeri (48.9\% identical amino acids), Aspegillus fumigatus (47.8 \% identical amino acids) and Aspergillus clavatus (46.5\% identical amino acids). Also, the ORF10 protein shared $31.9 \%$ identical amino acid residues with the previously reported CefT protein (CAD32176) of A. chrysogenum [15]. The low percentage of identity between cefT and ORF10p suggests that they transport different substrates in

320 this fungus.

Computer analysis of the predicted ORF10 protein with the TopPred2-Topology program of the membrane protein database (http://www.bioweb.pasteur.fr/seqanal/interfaces/toppred.html) indicated that it contains 12 transmembrane spanning (TSM) domains. In the predicted membrane topology, the carboxyl and amino ends are in the internal face of the membrane, that it is a characteristic of MFS proteins [30,31]. Therefore, the gene encoded by ORF10 has been named cefM (for microbody membrane protein).

Pex19 is a peroxin that interacts with peroxisomal membrane proteins for their import. Analysis of Pex19 binding sites (http://www.peroxisomedb.org/) in the CefM protein 330 showed one putative Pex19 binding site [26] between the amino acids 212 and 221 (Fig. 1). This observation suggested that CefM may be a peroxisome (microbody) membrane protein [32] (see below).

\section{Targeted inactivation of $\operatorname{cef} M$, results in a drastic reduction in cephalosporin production}

To determine if the CefM protein is involved in cephalosporin $\mathrm{C}$ biosynthesis or transport, we inactivated this ORF by double recombination with plasmid pDM (see Experimental Procedures) (Fig. 2A). Transformants of $A$. chrysogenum $\mathrm{C} 10$ with this 
plasmid were selected by resistance to phleomycin and screened by the double marker technique $[7,15,17]$. Clones showing a hyg ${ }^{S}$ phle $^{R}$ phenotype, indicating that double recombination had occurred, were selected. To confirm that targeted inactivation had occurred at the right position, seven transformants and the parental strain $A$. chrysogenum $\mathrm{C} 10$ (positive control), were analyzed by Southern blot hybridization (Fig. 2B and C) with a $608 \mathrm{bp} \mathrm{SalI} \mathrm{fragment} \mathrm{of} \mathrm{the} \mathrm{cefM} \mathrm{gene} \mathrm{as} \mathrm{probe} \mathrm{(Fig.} \mathrm{2A).} \mathrm{Results}$ showed that the parental strain A. chrysogenum C10 (Fig. 2B, lane 8) hybridized with a genomic DNA band of $3.8 \mathrm{~kb}$; however, in the transformant TDM-139 (for transformants disrupted in $c e f \underline{M}$ ), the $3.8 \mathrm{~kb}$ hybridization band was converted into one band of $5.3 \mathrm{~kb}$, as expected, by a canonical double recombination (Fig. 2B; lane 6). A $5.3 \mathrm{~kb}$ hybridization signal was found when the ble gene was used as probe as expected, 350 confirming that the endogenous cefM gene has been disrupted (Fig. 2C, lane 6). Other transformants still showed the original $3.8 \mathrm{~kb}$ band (see Fig. 2B, lane 4), indicating that cef $M$ gene replacement had not occurred and the plasmid integration was ectopic.

The disrupted mutant TDM-139 and A. chrysogenum C10 as control strain were cultured in defined cephalosporin production DP medium. Results of the fermentations showed (Fig. 3A) that the TDM-139 strain growth rate is similar to that of the parental strain until the 72 hours and thereafter the TDM-139 strain did not show the characteristic lysis phase of the parental strain. Analyses of the culture broth supernatant by bioassay (Fig. 3B) and HPLC (Fig. 3C) showed that the specific cephalosporin C biosynthesis in the disrupted strain was drastically reduced. Also, analysis by HPLC of 360 TDM-139 culture broth supernatant showed a $91.5 \%$ reduction in the specific production of extracellular penicillins (IPN and PenN) (Fig. 3D). Further HPLC analysis of the residual penicillins (see below) showed that the penicillin in this mixture was mostly penicillin $\mathrm{N}$ (see below).

\section{The TDM-139 strain accumulate intracellular PenN}

To study if the protein encoded by the $c e f M$ gene was involved in the PenN transport to microbodies or to the culture medium, the intracellular PenN levels were measured in cell extracts of the disrupted transformant TDM-139 and the parental strain $A$. chrysogenum C10 grown in DP medium for $96 \mathrm{~h}, 120 \mathrm{~h}$ and $144 \mathrm{~h}$. Cell-free extracts of

370 both $A$. chrysogenum strains were treated with 2,3,4,6-tetra- $O$-acetyl- $\beta$-Dglucopyranosyl isotiocianate (GITC) and the derivatized penicillin compounds resolved by HPLC as described previously [7,33]. Results showed (Fig. 3E) relatively high intracellular PenN levels in the cefM-disrupted mutant at 96,120 and $144 \mathrm{~h}$ as compared to the parental strain. The intracellular PenN levels were approximately sevenfold 375 higher in the TDM-139 disrupted mutant than in the parental strain A. chrysogenum C10. Taken together these results indicate that the cef $M$ mutant is unable to synthesize cephalosporin due to a lack in PenN transport related to its conversion to cephalosporin and as a result a significant amount of intracellular PenN is accumulated.

380 Complementation of the cefM mutation restores CPC biosynthesis and normal intracelluiar PenN levels

For complementation studies plasmid pCM bearing the intact cefM gene with its own promoter (Fig. 4A) was transformed into the TDM-139 mutant and transformants were selected by resistance to hygromycin. Five transformants that showed resistance to 385 hygromycin were selected at random, and their EcoRI-digested genomic DNA was hybridized with a $608 \mathrm{pb}$ fragment of the $c e f M$ gene as probe (Fig. 4A). Results showed that all five transformants (Fig. 4B; lanes 1, 2, 3, 4 and 5) gave hybridization with a DNA band of $4.8 \mathrm{~kb}$ in addition to the endogenous $5.3 \mathrm{~kb}$ hybridization band 
(corresponding to the disrupted cefM gene in the host TDM-139 mutant; Fig. 4B, lane 390 6), indicating that the insertion of plasmid pCM had occurred without reorganization in the transformants.

The effect of complementation of cef $M$ on cephalosporin $C$ production was studied with three different TCM transformants (for transformants complemented in cefM). Results showed that in transformants TCM-27, TCM-28 and TCM-35, the growth rate (Fig. 3A)

395 and the specific cephalosporin production (Fig. 3B and C) was restored to levels similar to those of the parental A. chrysogenum C10 strain. Analysis of extracellular (Fig. 3D) and intracellular (Fig. 3E) penicillin levels by HPLC showed that the penicillin N level was restored in the three TCM transformants to the same low level as in the parental strain $A$. chrysogenum C10 (Fig. 3E). Since complementation with cefM restores 400 cephalosporin production, it is clear that all other genes of the cephaplosporin pathway are functional.

\section{Disruption of cells releases compartimentalized PenN allowing in vitro conversion to cephalosporins}

405 All other genes of the cephalosporin pathway appeared to be functional in the cefMdisrupted mutant. This was confirmed by the in vitro conversion of PenN to $\mathrm{CPC}$ using cell-free extracts of the transformants TDM-139 (disrupted in cefM), TCM-27 (complemented) and the parental strain grown in DP medium for $144 \mathrm{~h}$. Results showed (Table 1) that the expandase/hydroxylase (converting Pen $\mathrm{N}$ to DAC) and DAC 410 acetyltransferase (converting DAC to CPC) activities were present in the disrupted strain as well as in the others, because there was in vitro CPC synthesis. This CPC synthesis was higher in the TDM-139 than in the parental and the complemented strains, probably due to the PenN accumulation in the cefM disrupted strain. The endogenous PenN is converted to $\mathrm{CPC}$ in the cell-free extracts, when the compartmentalized intermediates are released.

\section{Transformants containing functional cefM-GFP fusions produce cephalosporin}

Since the bioinformatic analysis showed that cef $M$ may interact with peroxin Pex 19, the subcellular location of the CefM protein in A. chrysogenum was studied in vivo by using GFP as reporter. This experiment required the utilization of one mutant lacking CefM as host strain for the fused cefM-GFP gene, in order to be sure that the GFP protein is targeted to the proper location by a functional CefM. For this propose, the TDM-139 mutant (disrupted in the cefM gene) was transformed with plasmid pcefM-GFP (Fig. $5 \mathrm{~A})$. This plasmid contains the $c e f M$ promoter $(1 \mathrm{~kb})$ upstream of a $c e f M-G F P$ hybrid gene that encoded a protein consisting of the 482 amino acids of the CefM fused inframe to the N-terminal end of the GFP.

The pcefM-GFP transformants were tested for cephalosporin production by the agar plug method obtaining two transformants that showed a similar cephalosporin production than $A$. chrysogenum $\mathrm{C} 10$. Total DNA was extracted from the blocked

430 mutant, from these two transformants, from mutant TDM-139 and from the parental strain A. chrysogenum C10; the DNAs were digested with a mixture of BamHI-MluI and hybridized with a $608 \mathrm{pb} S a l \mathrm{I}$ probe of the $c e f M$ gene. Results showed (Fig. 5B) that the probe hybridized with a band of $3.3 \mathrm{~kb}$, as expected (Fig. 5B lanes 1 and 2), indicating that the cefM-GFP hybrid gene was integrated in a non-reorganized form. The $7.4 \mathrm{~kb}$ hybridization band corresponded to the endogenous hybridizing band in the cefM disrupted mutant used as host strain (Fig. 5B; lane 3). The fused CefM-GFP protein in these two transformants is functional since it restored cephalosporin production to the blocked mutant. 
440 The fused CefM-GFP protein remains intact in the integral membrane proteins fraction of a TcefM-GFP transformant

To exclude the possibility that the GFP might be cleaved from the fused CefM-GFP protein, western analysis (Fig. 5C) of the pellet including integral membrane proteins was carried out using extracts of the TcefM-GFP36 transformant (Fig. 5C, lane 3) and the untransformed mutant TDM-139 (lane 2) and the parental strain A. chrysogenum C10 (lane 1). The results showed unequivocally that the CefM-GFP fusion protein remained intact. The fused CefM-GFP showed an estimated molecular mass of 79.2 $\mathrm{kDa}$ (Fig. 5C, lane 3), as expected, whereas a control sample containing free GFP (Roche Diagnostics Corp., Indianapolis, IN, U.S.A. Fig. 5C, lane 4) showed a molecular mass of $27 \mathrm{kDa}$. No GFP was observed in untransformed strains (lanes 1 and 2).

\section{The CefM-GFP hybrid protein is located in intracellular microbodies}

The TcefM-GFP36 transformant was used to determine the subcellular localization of the CefM-GFP hybrid protein (Fig. 6). The parental and the complemented strains grow and differentiate into typical arthrospores chains that are associated with high cephalosporin production (see discussion) (Fig. 6, panels in column A). However the formation of arthrospores in the disrupted strain TDM-139 was impaired (column B). Comparison of phase-contrast (Fig. 6 column C I), fluorescence images (Fig. 6 C II) and merged images (Fig. $6 \mathrm{C} \mathrm{III)} \mathrm{showed} \mathrm{that} \mathrm{the} \mathrm{CefM-GFP} \mathrm{hybrid} \mathrm{protein} \mathrm{was} \mathrm{targeted} \mathrm{to}$ 460 a type of medium-sized microbodies, where they produce punctuated fluorescence as shown in the enlarged photograph of one hypha (Fig. 7). This kind of fluorescence was characteristic of the GFP-PTS fusions that targeted to peroxisomes [34]. The abundance of these microbodies in the A. chrysogenum $\mathrm{Cl0}$ strain is probably related to the high level of cephalosporin production in this improved mutant strain.

\section{DISCUSSION}

Compartmentalization of specific reactions of the $\beta$-lactam biosynthesis pathways 470 provides a way to control this pathway by holding together enzymes with their substrates inside organelles [12]. In Penicillium chrysogenum specific steps of the $\beta$ lactam biosynthesis pathway are compartmentalized; the first two enzymes (ACV synthetase and IPN synthase) occur in the cytosol $[12,13,35]$ and the last step of the pathway in peroxisomes $[13,14,36]$.

475 In $A$. chrysogenum several enzymes of the cephalosporin biosynthesis pathway including ACV synthetase [37], IPN synthase [38], deacetoxycephalosporin C synthasehydroxylase $[39,40]$ and DAC acetyltransferase $[5,41]$ seem to be located in the cytosol $[11,12]$. A central step of this biosynthetic pathway is the poorly-known conversion of IPN to PenN [33] that is catalyzed by the isopenicillin N-CoA synthethase and 480 isopenicillin $\mathrm{N}-\mathrm{CoA}$ epimerase proteins encoded by the cefD1 and cefD2 genes, respectively [7]. The peroxisomal targeting signals (PTS) allow the sorting of peroxisomal matrix proteins. There are two types of peroxisomal targeting signals: the C-terminal PTS-1 with consensus sequence SKL and the N-terminal nonapeptide PTS-2 with consensus sequence $(\mathrm{R} / \mathrm{L})(\mathrm{L} / \mathrm{V} / \mathrm{I})-X_{5^{-}}(\mathrm{H} / \mathrm{Q})(\mathrm{L} / \mathrm{A})$ [19]. We have observed that 485 CefD1 and CefD2 proteins contain a C-terminal PTS1 peroxisomal targeting signal for peroxisomal localization [42]. CefD1 contains a putative PTS1 whereas CefD2 contains both PST1 and PST2 signals. Jayatilake et al [43], Baldwin et al [44] and Lübbe et al. [45] studied the in vitro conversion of isopenicillin into penicillin $\mathrm{N}$ in cell-free extracts 
and found that it was optimal at $\mathrm{pH} 7$; this same $\mathrm{pH}$ was reported for the peroxisomal 490 lumen of $P$. chrysogenum that is slightly higher than that of the cytosol [46]. Therefore, the epimerization of IPN to PenN seems to take place in peroxisomes and requires specific transport steps of intermediates through peroxisomal membranes. The presence of cefT [15] and cefM in the cephalosporin gene clusters is consistent with an increased body of evidence showing that export genes are frequently linked to antibiotic 495 biosynthesis genes [47].

The secretion of different secondary metabolites from the producer strains is a subject of interest [48]. Despite the industrial relevance of many of the secondary metabolites, only in a few cases the membrane proteins involved in secretion of those metabolites have been identified and validated by gene disruption. Particular attention deserves the 500 transporters involved in penicillin or cephalosporin secretion, because of the very large amounts of these $\beta$-lactams that need to be secreted in the industrial strains.

It is clear from the Results of this work that the cefM gene located downstream of the cefDl gene encoding the proposed isopenicillinyl-CoA ligase of the two component epimerization system [7,33] is essential for cephalosporin biosynthesis. The CefM 505 protein belongs to the MFS superfamily of proteins, particularly to Family 3 (drug efflux proteins), the same family of the CefT protein [15]. MFS transporters are single polypeptide secondary carriers that are capable of transporting small solutes and utilize the transmembrane electrochemical gradient of protons or sodium ions to drive the extrusion of drugs from the cell [48].

510 CefM contains 12 TMS domains and might be located in the membrane of microbodies or other intracellular organelles (Fig. 8). The presence of a consensus Pex19-interaction motif (residues 212-221) in CefM suggests that the CefM protein is likely to be recruited by Pex19 to the microbody membrane. This motif is present in structural peroxisomal or microbody membrane proteins [26,32].

515 The microbody location of CefM was fully supported by the results of the fluorescent microscopy analysis using a functional CefM-GFP fusion. Using high resolution phasecontrast and fluorescence microscopy the fusion protein was found to be located in medium-sized microbodies in the hyphae and particularly in the arthrospore chains of $A$. chrysogenum. The fluorescent microbodies were abundant in differentiating $A$.

520 chrysogenum cells after $72 \mathrm{~h}$ of cultivation coinciding with the phase of active cephalosporin biosynthesis

This finding is very interesting since for many years it has been known that there is a direct correlation between arthrospore formation and the cephalosporin $\mathrm{C}$ biosynthetic ability [49]. It is now clear from the results reported in this article that the CefMcontaining microbodies are particularly abundant in hyphae that are starting to differentiate and in the arthrospores themselves.

The microbodies that we observed are very similar to the peroxisomes identified in $P$. chrysogenum that contain a PST1 peroxisomal-targeted GFP [34]. However, we do not exclude at this time that the fluorescent microbodies might be a more specific cephalosporin biosynthesis-related type of 'lipid bodies'.

The substrate transported by the CefM protein out of the microbodies appears to be PenN. Since ACV and IPN are synthesized in the cytosol by cytoplasmic ACV synthetase and IPN synthase [12,50], the IPN has to be transported into peroxisomes or microbodies, as it occurs in P. chrysogenum, during penicillin biosynthesis [51]. After 535 epimerization by the two-component CefD1-CefD2 peroxisomal epimerization system in Acremonium, Pen $\mathrm{N}$ is likely to be transported back into the cytosol, since the three last enzymes of the cephalosporin pathway have been reported to be soluble $[11,12]$. 
The entry of IPN into peroxisomes seems to be coupled to its activation to isopenicillinCoA by the CefD1 acyl-CoA ligase. Very long acyl-CoA ligases similar to CefD1 are known to be involved in transport of fatty acids. Therefore, the exit of an early intermediate of the pathway to the cytosol is the most likely transport step performed by CefM (Fig. 8). This role is consistent with the increase in intracellular PenN and the drastic reduction of the extracellular PenN and of formation of cephalosporin in the TDM-139 mutant disrupted in cefM. If the PenN can not be transported out of the microbody, the entire pathway is blocked and the early steps of the pathway are feedback inhibited.

The cefT and cef $M$ genes are located in the opposite ends of the "early" cephalosporin gene cluster, and encode transporters with clearly different functions. Mutants disrupted in cefT still produce normal levels of cephalosporin whereas, as shown in this article, a

550 mutant disrupted in cef $M$ fails to produce cephalosporin although it contains the enzymes for the conversion of PenN to CPC. The CefT protein was proposed to be involved in cephalosporin secretion from the cell [15], whereas CefM is clearly located in microbodies and is involved in the transport of an early intermediate of the cephalosporin pathway.

555 In summary, the cephalosporin pathway in A. chrysogenum provides a good example of compartmentalization of precursors and enzymes. Therefore, the CefM transporter plays a critical role in their proper localization and is essential for cephalosporin biosynthesis.

\section{ACKNOWLEDGEMENTS}

This work was supported by grants of the European Union (Eurofung QLRT-199900729I) and DSM (Delft, Holland). F. Teijeira received a FPU predoctoral fellowship from the Ministry of Education and Science (Madrid). C. García-Estrada is supported

565 by the Torres Quevedo Program (PTQ04-3-0411). We acknowledge the support of Roel Bovenberg, DSM (Holland) and the excellent technical assistance of A. Sánchez, B. Martín, J. Merino, A. Casenave and B. Aguado.

\section{REFERENCES}

1 Demain, A. L., Martín, J. F. and Elander, R. P. (1998) Penicillin biochemistry and genetics. In Penicillin, a paradigm for biotechnology, R.I Mateles, ed. (Chicago, USA: Candida, Co.), pp. 93-113

5752 Rodríguez-Sáiz, M., Lembo, M., Bertetti, L., Muraca, R., Velasco, J., Malcangi, A., de la Fuente, J. L. and Barredo, J. L. (2004) Strain improvement for cephalosporin production by Acremonium chrysogenum using geneticin as a suitable transformation marker. FEMS Microbiol. Lett. 235, 43-49

3 Aharonowitz, Y., Cohen, G. and Martin, J. F. (1992) Penicillin and cephalosporin biosynthetic genes: structure, organization, regulation, and evolution. Annu. Rev. Microbiol. 46, 461-495

4 Gutiérrez, S., Díez, B., Montenegro, E. and Martín, J. F. (1991) Characterization of the Cephalosporium acremonium pcbAB gene encoding alpha-aminoadipylcysteinyl-valine synthetase, a large multidomain peptide synthetase: linkage to the $p c b C$ gene as a cluster of early cephalosporin biosynthetic genes and evidence of multiple functional domains. J. Bacteriol. 173, 2354-2365 
5 Gutiérrez, S., Velasco, J., Fernández, F.J. and Martín, J.F. (1992) The cefG gene of Cephalosporium acremonium is linked to the cefEF gene and encodes a deacetylcephalosporin $\mathrm{C}$ acetyltransferase closely related to homoserine Oacetyltransferase J. Bacteriol. 174, 3056- 3064

6 Gutiérrez, S., Fierro, F., Casqueiro, J. and Martín, J. F. (1999) Gene organization and plasticity of the $\beta$-lactam genes in different filamentous fungi. Antonie van Leeuwenhoek. 75, 81-94

7 Ullán, R. V., Casqueiro, J., Bañuelos, O., Fernández, F. J., Gutiérrez, S. and Martín, J. F. (2002) A novel epimerization system in fungal secondary metabolism involved in the conversion of isopenicillin $\mathrm{N}$ into penicillin $\mathrm{N}$ in Acremonium chrysogenum . J. Biol. Chem. 277, 46216-46225

8 Díez, B., Gutiérrez, S., Barredo, J. L., van Solingen, P., van der Voort, L. H. M. and Martín, J. F. (1990) The cluster of penicillin biosynthetic genes. Identification and characterization of the $p c b A B$ gene encoding the alpha-aminoadipyl-cysteinyl-valine synthetase and linkage to the $p c b C$ and $p e n D E$ genes. J. Biol. Chem. 265, 1635816365

9 Fierro, F., Gutiérrez, S., Díez, B. and Martín, J. F. (1993) Resolution of four large chromosomes in penicillin producing filamentous fungi: The penicillin gene cluster is located on chromosome II (9.6 Mb) in Penicillium notatum and chromosome I (10.4 Mb) in Penicillium chrysogenum. Mol. Gen. Genet. 241, 573-578

10 Liras, P. and Martín, J. F. (2006) Gene clusters for $\beta$-lactam antibiotics and control of their expression: Why have clusters been formed and where do they come from?. Int. Microbiol. 9, 9-19

61011 van de Kamp, M., Driessen, A. J. and Konings, W. N. (1999) Compartmentalization and transport in beta-lactam antibiotic biosynthesis by filamentous fungi. Antonie Van Leeuwenhoek. 75, 41-78

12 Evers, M. E., Trip, H., van den Berg, M. A., Bovenberg, R. A and Driessen, A. J. (2004) Compartmentalization and transport in beta-lactam antibiotics biosynthesis.

615 Adv Biochem Eng Biotechnol. 88: 111-135

13 Müller, W. H., van der Krift, T. P., Krouwer, A. J., Wosten, H. A., van der Voort, L. H., Smaal, E. B. and Verkleij, A. J. (1991) Localization of the pathway of the penicillin biosynthesis in Penicillium chrysogenum. EMBO J 10, 489-495

14 Müller, W. H., Bovenberg, R. A., Groothuis, M. H., Kattevilder, F., Smaal, E. B., Van der Voort, L. H. and Verkleij, A. J. (1992) Involvement of microbodies in penicillin biosynthesis. Biochim. Biophys. Acta. 1116, 210-213

15 Ullán, R. V., Liu, G., Casqueiro, J., Gutiérrez, S., Bañuelos, O. and Martín, J. F. (2002) The cefT gene of Acremonium chrysogenum C10 encodes a putative multidrug efflux pump protein that significantly increases cephalosporin $\mathrm{C}$ production. Mol. Genet. Genomics. 267, 673-683

16 Andrade, A. C., Del Sorbo, G., Van Nistelrooy, J. G. and Waard, M. A. (2000) The ABC transporter AtrB from Aspergillus nidulans mediates resistance to all major classes of fungicides and some natural toxic compounds. Microbiology. 146, 19871997

63017 Liu, G., Casqueiro, J., Bañuelos, O., Cardoza, R. E., Gutiérrez, S. and Martín, J.F. (2001) Targeted inactivation of the $m e c B$ gene, encoding cystathionine-gammalyase, shows that the reverse transsulfuration pathway is required for high-level cephalosporin biosynthesis in Acremonium chrysogenum $\mathrm{C} 10$ but not for methionine induction of the cephalosporin genes. J. Bacteriol. 183, 1765-1772

63518 Heiland, I. and Erdmann, R. (2006) Investigation of peroxisome biogenesis revealed possible new roles for autophagy components. Autophagy. 2, 209-211 
19 Mukai, S. and Fujiki, Y. (2006) Molecular mechanisms of import of peroxisometargeting signal type 2 (PTS2) proteins by PTS2 receptor Pex7p and PTS1 receptor Pex5pL. J. Biol. Chem. 281, 37311-37320

20 Erdmann, R. and Blobel, G. (1996) Identification of Pex13p a peroxisomal membrane receptor for the PTS1 recognition factor. J. Cell. Biol. 135, 111-121

21 Gould, S. J., Kalish, J. E., Morrell, J. C., Bjorkman, J., Urquhart, A. J. and Crane, D. I. (1996) Pex13p is an SH3 protein of the peroxisome membrane and a docking factor for the predominantly cytoplasmic PTS1 receptor. J. Cell. Biol. 135, 85-95

22 Dyer, J. M., McNew, J. A. and Goodman, J. M. (1996) The sorting sequence of the peroxisomal integral membrane protein PMP47 is contained within a short hydrophilic loop. J. Cell. Biol. 133, 269-280

23 Honsho, M., Hiroshige, T. and Fujiki, Y. (2002) The membrane biogenesis peroxin Pex16p. Topogenesis and functional roles in peroxisomal membrane assembly. J. Biol. Chem. 277, 44513-44524

24 Jones, J. M., Morrell, J. C. and Gould, S. J. (2001) Multiple distinct targeting signals in integral peroxisomal membrane proteins. J. Cell. Biol. 153,1141-1150

25 Van Ael, E. and Fransen, M. (2006) Targeting signals in peroxisomal membrane proteins. Biochim. Biophys. Acta. 1763, 1629-1638

26 Rottensteiner, H., Kramer, A., Lorenzen, S., Stein, K., Landgraf, C., VolkmerEngert, R. and Erdmann, R. (2004) Peroxisomal membrane proteins contain common Pex19p-binding sites that are an integral part of their targeting signals. Mol. Biol. Cell. 15, 3406-3417

27 Ullán, R.V., Godio, R.P., Teijeira, F., Vaca, I., García-Estrada, C., Feltrer, R., Kosalková, K., Martín, J.F. (2008). RNA-silencing in Penicillium chrysogenum and Acremonium chrysogenum: Validation studies using $\beta$-lactam genes expression. $\mathrm{J}$ Microbiol Methods 75, 209-218

28 Fernández-Ábalos, J. M., Fox, H., Pitt, C., Wells, B. and Doonan, J. H. (1998) Plantadapted green fluorescent protein is a versatile vital reporter for gene expression, protein localization and mitosis in the filamentous fungus, Aspergillus nidulans. Mol. Microbiol. 27, 121-130

29 Ullán, R. V., Campoy, S., Casqueiro, J., Fernández, F. J. and Martín, J. F. (2007) Deacetylcephalosporin $\mathrm{C}$ production in Penicillium chrysogenum by expression of the isopenicillin $\mathrm{N}$ epimerization, ring expansion, and acetylation genes. Chem. Biol. 14, 329-339

30 Pao, S. S., Paulsen, I. T. and Saier, M. H. (1998) Major facilitator superfamily. Microbiol. Mol. Biol. Rev. 62, 1-34

31 Del Sorbo, G., Schoonbeek, H. and De Waard, M. A. (2000) Fungal transporters involved in efflux of natural toxic compounds and fungicides. Fungal Genet. Biol.

\section{$67530,1-15$}

32 Heiland, I. and Erdmann, R. (2005) Biogenesis of peroxisomes. Topogenesis of the peroxisomal membrane and matrix proteins. FEBS J. 272, 2362-2372

33 Ullán, R. V., Casqueiro, J., Naranjo, L., Vaca, I. and Martín, J. F. (2004) Expression of cefD2 and the conversion of isopenicillin $\mathrm{N}$ into penicillin $\mathrm{N}$ by the twocomponent epimerase system are rate-limiting steps in cephalosporin biosynthesis. Mol. Genet. Genomics. 272, 562-570

34 van der Klei, I. J. and Veenhuis, M. (2006) Yeast and filamentous fungi as model organisms in microbody research. Biochim. Biophys. Acta. 1763, 1364-1373

35 Ramos, F. R., López-Nieto, M. J. and Martín, J. F. (1985) Isopenicillin N synthetase of Penicillium chrysogenum, an enzyme that converts delta-(L-alpha-aminoadipyl)- 
L-cysteinyl-D-valine to isopenicillin N. Antimicrob. Agents. Chemother. 27, 380387

36 Müller, W. H., Essers, J., Humbel, B. M. and Verkleij, A. J. (1995) Enrichment of Penicillium chrysogenum microbodies by isopycnic centrifugation in nycodenz as visualized with immuno-electron microscopy. Biochim. Biophys. Acta. 1245, 215220

37 Baldwin, J. E., Bird, J. W., Field, R. A., O' Callaghan, N. M. and Schoffield, C. J. (1990) Isolation and partial characterisation of ACV synthetase from Cephalosporium acremonium and Streptomyces clavuligerus. J. Antibiot. 43, 10551057

38 Samsom, S. M., Belagaje, R., Blankenship, D. T., Chapman, J. L., Perry, D., Skatrud, P. L., van Frank, R. M., Abraham, E. P., Baldwin, J. E., Queener, S. W. and Ingolia, T. D. (1985) Isolation, sequence determination and expression in Escherichia coli of the isopenicillin $\mathrm{N}$ synthetase gene from Cephalosporium acremonium. Nature. 318, 191-194

39 Dotzlaf, J. E. and Yeh, W. K. (1987) Copurification and characterization of deacetoxycephalosporin C synthetase/hydroxylase from Cephalosporium acremonium. J. Bacteriol. 169, 1611-1618

40 Samsom, S. M., Dotzlaf, J. F., Slisz, M. L., Becker, G. W., van Frank, R. M., Veal,

L. E., Yeh, W. K., Miller, J. R., Queener, S. W. and Ingolia, T. D. (1987) Cloning and expression of the fungal expandase/hydroxylase gene involved in cephalosporin biosynthesis. Biotechnology 5, 1207-1214

41 Velasco, J., Gutiérrez, S., Campoy, S. and Martín, J. F. (1999) Molecular characterization of the Acremonium chrysogemum cefG gene product: the native deacetylcephalosporin $\mathrm{C}$ acetyltransferase is not processed into subunits. Biochem. J. 337, 379-385

42 Reumann, S. (2004) Specification of the peroxisome targeting signals type 1 and type 2 of plant peroxisomes by bioinformatics analyses. Plant Physiol. 135, 783-800

43 Jayatilake, S., Huddleston, J. A. and Abraham, E. P. (1981) Conversion of isopenicillin $\mathrm{N}$ into penicillin $\mathrm{N}$ in cell-free extracts of Cephalosporium acremonium. Biochem. J. 194, 645-647

44 Baldwin, J. E., Keeping, J. W., Singh, P. D. and Vallejo, C. A. (1981) Cell free conversion of isopenicillin $\mathrm{N}$ into deacetoxycephalosporin $\mathrm{C}$ by Cephalosporium acremonium mutant M-0198. Biochem. J. 194, 649-651

45 Lübbe, C., Wolfe, S. and Demain, A. L. (1986) Isopenicillin N epimerase activity in a high cephalosporinproducing strain of Cephalosporium acremonium. Appl. Microbiol. Biotechnol. 23, 367-368

46 van der Lende, T. R., Breeuwer, P., Abee, T., Konings, W. N. and Driessen, A. J. (2002) Assessment of the microbody luminal $\mathrm{pH}$ in the filamentous fungus Penicillium chrysogenum. Biochim. Biophys. Acta. 1589, 104-111

47 Martín, J. F. and Liras, P. (1989) Organization and expression of genes involved in the biosynthesis of antibiotics and other secondary metabolites. Annu Rev Microbiol 43, 173-206

48 Martín, J. F., Casqueiro, J. and Liras, P. (2005) Secretion systems for secondary metabolites: how producer cells send out messages of intercellular communication. Curr. Opin. Microbiol. 8, 282-293

49 Dreyer, J., Eichhorn, H., Friedlin, E., Kürnsteiner, H. and Kück, U. (2007) A homologue of the Aspergillus velvet gene regulates both cephalosporin C biosynthesis and hyphal fragmentation in Acremonium chrysogenum. Appl. Environ. Microbiol. 73, 3412-3422 
50 van der Lende, T. R., van de Kamp, M., Berg, M., Sjollema, K., Bovenberg, R. A., Veenhuis, M., Konings, W. N. and Driessen, A. J. (2002) delta-(L-alphaAminoadipyl)-L-cysteinyl-D-valine synthetase, that mediates the first committed step in penicillin biosynthesis, is a cytosolic enzyme. Fungal Genet. Biol. 37, 49-55

51 García-Estrada, C., Vaca, I., Lamas-Maceiras, M. and Martín, J. F. (2007) In vivo transport of the intermediates of the penicillin biosynthetic pathway in tailored strains of Penicillium chrysogenum. Appl. Microbiol. Biotechnol. 76, 169-182 
Figure 1. Alignment of the deduced amino acid sequences of protein encoded by the cefM gene of $A$. chrysogenum with the protein encoded by the cefT gene of $A$. chrysogenum and the hipotetical MFS proteins of $A$. clavatus (XP_001273827), $A$. fumigatus (XP_748433) and $\boldsymbol{N}$. fischeri (XP_001258746). The 12 TMS segments are overlined with a solid bar, and the characteristic motifs (A, B, C, D 2 and G) of the MFS family are overlined with thin lines. Only the identical amino acids are shaded. The proteins were aligned using the ClustalX program. Note that the amino acid sequenced of the Pex19p binding site in CefM protein (residues 212-221) is boxed.

Figure 2. Disruption of cefM by a double crossing-over recombination and molecular analysis of the transformants.

(A) Scheme of disruption of cefM by gene replacement with the pDM plasmid. The size of fragments expected after the double crossing-over is indicated. (B and $\mathbf{C}$ ) Southern blot hybridizations of EcoRI-digested genomic DNA from several transformants with labeled probes internal to the $\operatorname{cef} M(\mathrm{~B})$ or ble $(\mathbf{C})$ genes. Lane $\mathrm{M}$, size markers (Lambda DNA / HindIII digested); lanes 1, transformant TDM-38; 2, TDM-57; 3, TDM-64; 4, TDM-87; 5, TDM-131; 6, TDM-139; 7, TDM153; 8, A. chrysogenum C10. Note that transformants TDM-87 and TDM-139 contain an intact pDM construction (lanes 4 and

765 6). Transformant TDM139 shows the correct gene replacement (lane 6). The size of the hybridization bands (in $\mathrm{kb}$ ) are indicated on the right.

Figure 3. Growth kinetics and $\beta$-lactam production in the parental strain, the cefM-disrupted mutant and the complemented transformants.

770 Growth kinetics (A), cephalosporin (B and C) and extracellular penicillin (D) production of $A$. chrysogenum C10, the disrupted mutant TDM-139 and the complemented transformants TCM-27. (E) Intracellular level of penicillin N. The error bars indicate the standard deviations of three independent cultures. In panel $\mathbf{B}$ analysis of the total cephalosporin production in the culture broths was made by bioasays using

775 E. coli ESS2231 as test strain. Panels C and D show HPLC analysis of the cephalosporin $\mathrm{C}(\mathbf{C})$ and extracellular penicillin $(\mathrm{IPN}+\mathrm{PenN})$ production $(\mathbf{D})$ in the culture broths. (E) HPLC analysis of the intracellular PenN. The same results were obtained with the TCM-28 and TCM-35 transformants (not plotted to avoid overlapping of the lines).

Figure 4. Complementation in trans of the disrupted TDM-139 mutant with pCM.

(A) Plasmid pCM containing the cefM gene. (B) Southern blot hybridization of EcoRIdigested genomic DNA from five transformants, untransformed A. chrysogenum C10, and the disrupted mutant TDM-139, using as probe the $608 \mathrm{pb}$ SalI fragment internal to

785 the cefM gene. Lane M, size markers (Lambda DNA / HindIII digested); lanes 1, TCM9; 2, TCM-10; 3, TCM-27 4, TCM-28; 5, TCM-35; 6, TDM-139 (disrupted mutant); 7, A. chrysogenum $\mathrm{C} 10$. The size of the hybridization bands (in $\mathrm{kb}$ ) are indicated on the right.

790 Figure 5. Southern and western blot analysis of the transformant carrying the fused cefM-GFP gene.

(A) Plasmid pcefM-GFP containing the cefM-GFP hybrid gene. (B) Southern blot hybridization of $M l u \mathrm{I}-\mathrm{BamHI}$ digested genomic DNA from transformants TcefMGFP36 (lane 1) and TcefM-GFP37 (lane 2) transformants, the wild type C10 (lane 3) 
and TDM-139 (lane 4) using as probe the $608 \mathrm{pb}$ SalI fragment internal to cefM. (C) Immunoblot analysis of the CefM-GFP fusion protein in the membrane fraction of the transformant TcefM-GFP36. Lane M, Bio-Rad Precision Protein Standards; Lanes 1, TDM-139; 2, C10; 3, TcefM-GFP36 and 4, free GFP. Immunodetection was performed with anti-GFP antibodies (see Experimental Procedures). The sizes of the hybridization bands are indicated on the right.

\section{Figure 6. Subcellular localization of the CefM protein.}

Hyphae and arthrospore chains of $A$. chrysogenum C10 (column A), the disrupted mutant TDM-139 (column B) and the complemented TcefM-GFP36 (column C). Strains were observed by phase-contrast microscopy (row I), or fluorescence microscopy (II); merged images or rows I and II (III). The samples in this figure were obtained from cultures grown for $72 \mathrm{~h}$ in CCM medium. The fluorescence was monitored for $96 \mathrm{~h}$. Note that the cefM-disrupted mutant (column B) shows impaired differentiation into arthrospores.

Figure 7. Enlarged detail of a hyphal fragment showing the localization of the CefM-GFP labelled microbodies.

Culture condition and staining procedures were as in Figure 6.

815 Figure 8. Model of localization of the different steps of the cephalosporin C biosynthetic pathway in $A$. chrysogenum showing the localization of the CefM transporter (shaded) in the membrane of microbodies (MB).

$\mathrm{ACV}, \delta$-L- $\alpha$-aminoadipyl-L-cysteinyl-D-valine. IPN, isopenicillin $\mathrm{N}$; PenN, penicillin $\mathrm{N}$; DAOC, deacetoxycephalosporin $\mathrm{C}$; DAC, deacetylcephalosporin C; CPC, cephalosporin $\mathrm{C}$. 
Table 1. CPC synthesis in cell-free extracts of the transformants TDM-139 and TCM-27 (derived from TDM-139 by complementation with cefM gene).

\begin{tabular}{|c|c|c|}
\hline Strain & Genotype & $\begin{array}{c}\text { Cephalosporin C } \\
\text { production } \\
\text { ng CPC/mg of myceli }\end{array}$ \\
\hline A. chrysogenum $\mathrm{C} 10$ & wild type & \\
\hline A. chrysogenum TDM-139 & $\operatorname{cefM}$ & $17.8 \pm 2.0$ \\
\hline A. chrysogenum TCM-27 & wild type & $7.1 \pm 0.5$ \\
\hline
\end{tabular}

The strains were grown in DP medium and mycelia were collected at 144 hours. Data are the average of three determinations. ${ }^{*}$ Standard deviation of the mean values. 
ORF10p (CefM) A. chrysogenum Ceft A. chrysogenum

A. fumigatus

A. clavatus

N. fischeri

-MVKAEEDSAAL---EAAIDNGRRHIVDFDGPTDPDNAVNWP 38 MANNSGTTTVQLDDVLERSSTLNTLNNIDTVQHHEPRTSFANNRQQAPAGGSSQSDATVGPRHKLVTFAPDDPENPKNWS 80 --------MDCRASRSTGAAAMSCEKSICPLDLEKNLVVQVENPTSG---CEVTDYVTSHVVDWDGPDDFARPVNWH 66 --10--MDHGKPQGWSTSSSDLEKNVIFHEHQTAD-----AVTQRDASNTVDWDGRDDPARPINWN 55

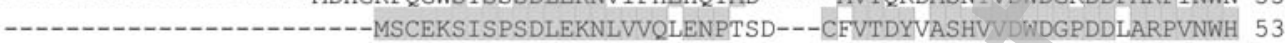

D2

$\underline{A}$

ORF10p (CefM) A. chrySOgenUm AARKWLNVFVLAAMTFIAALGSSIAAPGVNQAIVDFDSTSSILSSLIVSVYNVGLAIGPIIVAPLSEMYGRLIPYHVTNV 118 Ceft A. chrysogenum

A. fumigatus KAYKWYCTLVVSLTCFVVAFASSVISADIDGVMEEFNVS-ETAALVSISVFVVGFGVGPMVEAPLSEVYGRRIIYGSKLL 159

A. clavatus

N. fischeri KKRKWLNVTSVAFLTFLTPLASSMVAPAGGLVIETFNITSESLASFVVSIYLVGEAVGPLVLGPLSEIYGRLRIYQACNA 146 GRKKWVNVASVAMLTFLTPLASSMVAPAQALVMDSFDITSDTLGSFVISIYLVGFAVGPLVLGPLSEIYGRLRIYQMCNV 135 KKRKWLNVTSVAFLTFLTPLASSMVAPAGGLVIESFNITSESLASFVVSIYLVGEAVGPLVLGPLSEIYGRLRVYQACNA 133

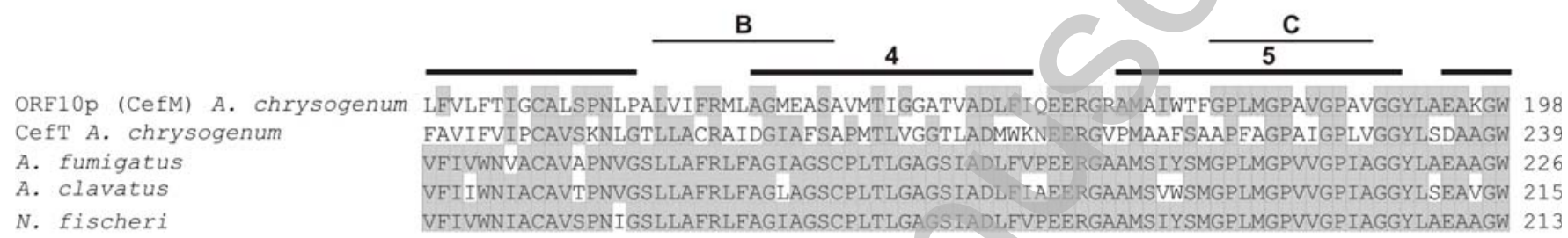

ORF10p (CefM) A. chrysogenUm RWVFWVVAGGGETTGMFFLIAR TYPPVLIORK NRLRQETGNPLLTSALADTSSRR-ARISRSVRRPLVLLERSPIVF 277 CefT A. chrysogenum RWLYWLLILSGIIWILITFTVPETYAPTILAKRARK RKSTGDPNHVTEQELDPRPISEQLRVFLTRPEQLLEGELIVL 319 A. fumigatus RWIFWVISMAGGAVFAFSLVFQTETYEPVLLQRRVDQLRKEAGDMTLRSKLAPNISAR-DNEIRSIVRPTKMLFLSPIVA 305

A. clavatus

N. fischeri RWI FWVIAMAAGGVFAFSVLFOTESYEPV LQQRVDRLSKETGNAELRSKLAPNIRPR-ENFIRSIVRPTKMLLLSPIVL 294 RWIFWVISMAGGAVFAFSLLFOTETYEPVLIORRADQLRKETGDMILRSKLAPNISAR-DNFIRSIVRPTKMLFLSPIVA 292

\section{$7 \quad 8$}

ORF10p (CefM) A. chrysogenum Ceft A. chrysogenum

A. fumigatus

A. clavatus

N. fischeri

LFSVFIAVVFSYQFLI VTIPSVFGEIYDFSLGQIGLSYLGIAAGLLLGNAIFGQASDRILS--KKSGGMELKPEFRLPL 355 LISLYMSVLYGLLYMF IAYPIV KGGKGYSSGKTGLMF IPVAVGVVLSACCSPFVNTHYIS-LAHFHGGKPPAEVRLIP 398 IFSVYLGIVYGYLYLLFTTITPVYQTTYQFSQGAAGLTYLGIGVGSLIGLLIFGTISDKILIYLTKQNDGVREPEFRMPP 385 LFS IY IAMGYGY LYLLFTTITSVEMTNYHFSQGAAGLTYLGIGIGSLVGLLVFGSVSDRILIYLTKRNNGVAEPEERMPP 374 IFSVYLGIVYG LYLLFT ITSVYQTTYQESQGAAGLTYLGIGVGSLI GLLIFGTISDKILIYLTKRNNGVREPEFRMPP 372

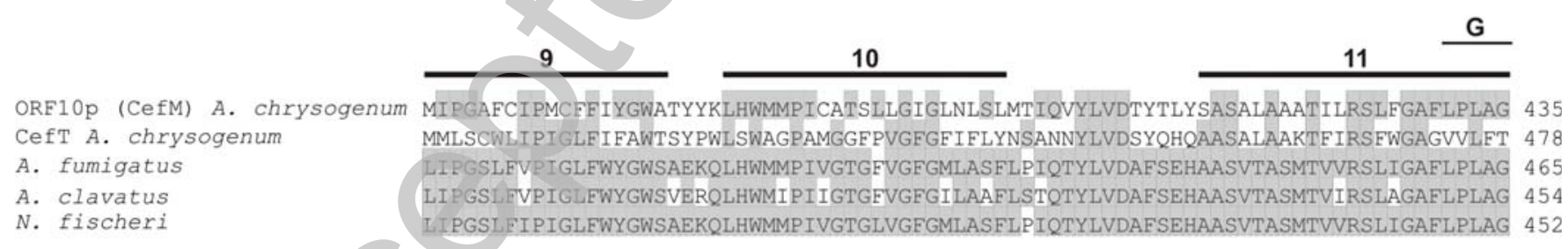

ORF10p (CefM) A. chrySOgenUM RPLYDALGLGWGNSTLFIAVALIPVPFLFIRYGEAIRTNRRFQPAL

A. fumigatus

A. clavatus

N. fischeri

KQMYSRLGDQWASSLIAFLALACCAIPFLFWKYGARIRARSKYAYAGDETPADVEKAKQRPAEAGVLADADDLRRAISYV 558 PAMYARLGLGWGNSMLGEIALTMLPLPVVFYYYGKKIRTYPAFQVTF PAMYARLGLGWGNSMLGEIALAMWPLPVFFFCYGKRIRALPLFNVTF PAMYARLGLGWGNSMLGEISLAMLPLPVVFYYYGKRIRTYPIFKVTP

Figure 1. Teijeira et al.

Licenced copy. Copying is not permitted, except with prior permission and as allowed by law. (C) 2008 The Authors Journal compilation (C) 2008 Biochemical Society 
Biochemical Journal Immediate Publication. Published on 08 Oct 2008 as manuscript BJ20081180

A
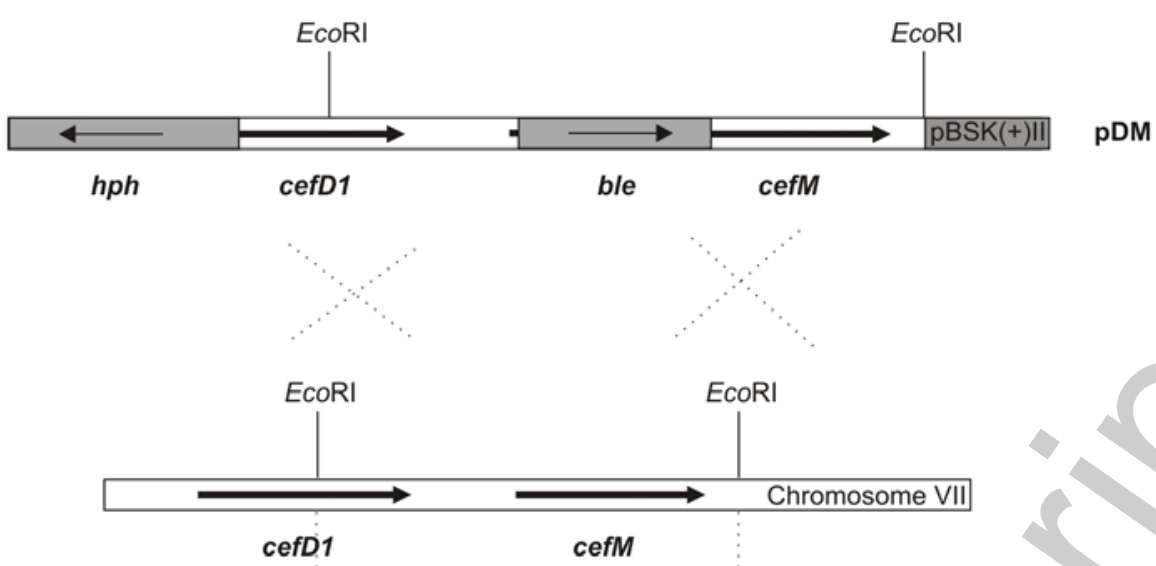

$3.8 \mathrm{~kb}$

Double crossing over

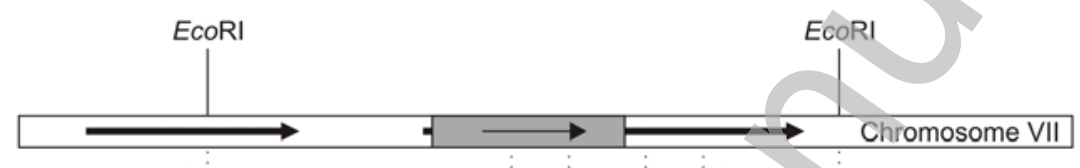

cefD1

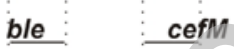

probe II probel

$5.3 \mathrm{~kb}$

B
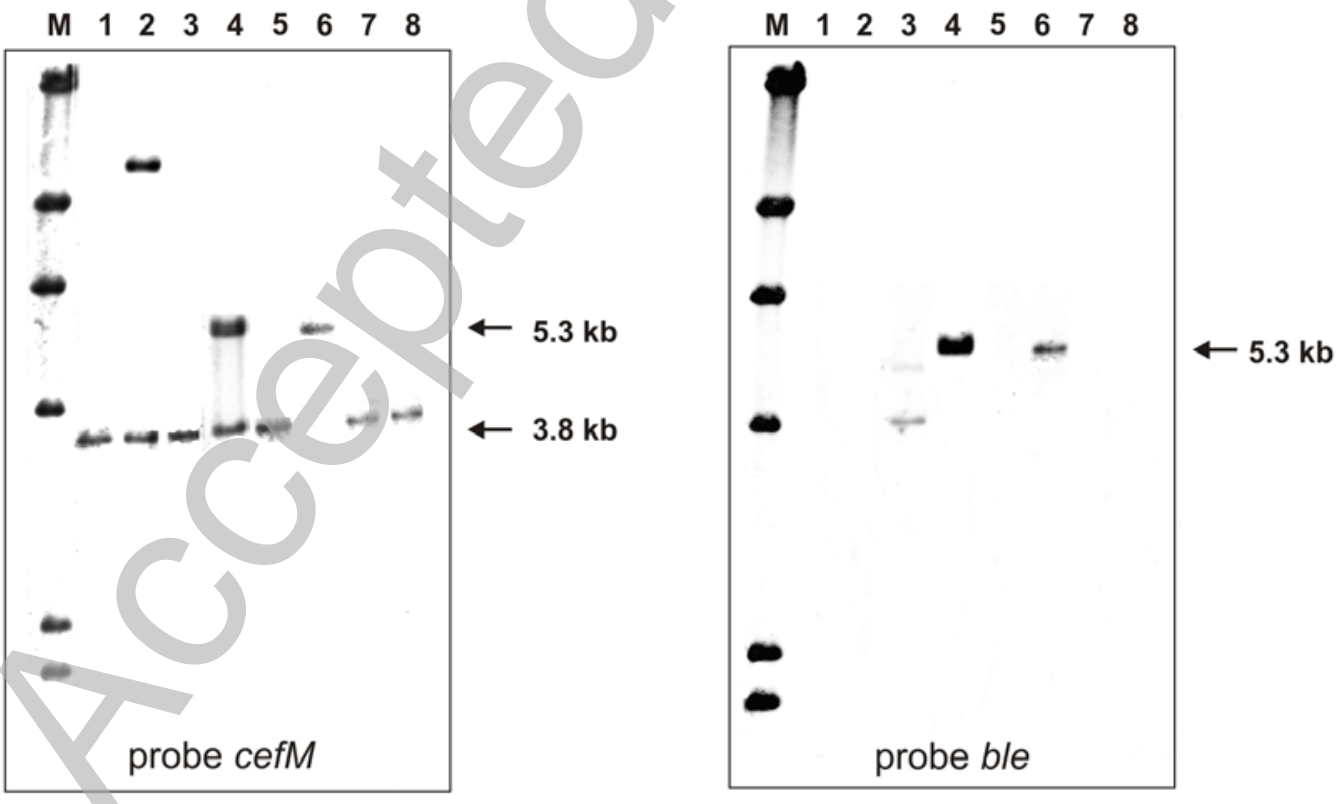

Figure 2. Teijeira et al.

Licenced copy. Copying is not permitted, except with prior permission and as allowed by law. (C) 2008 The Authors Journal compilation (C) 2008 Biochemical Society 
A

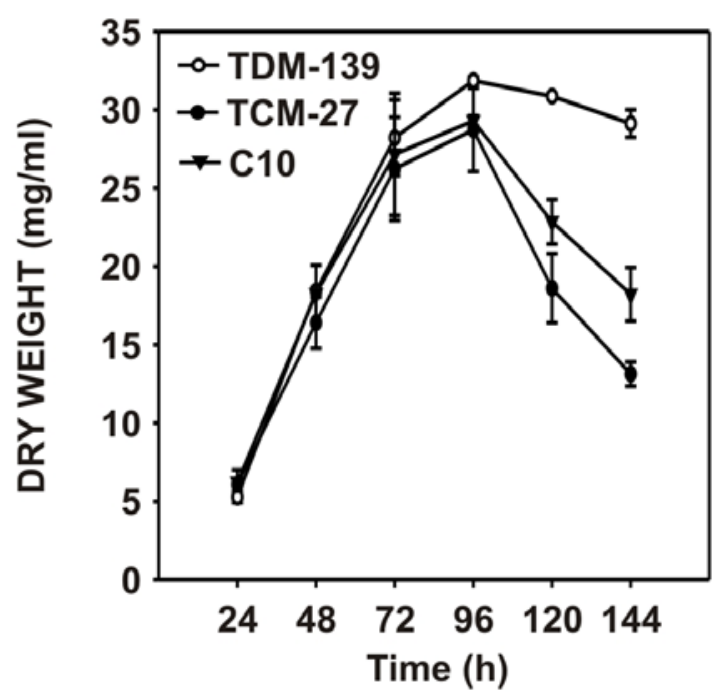

C

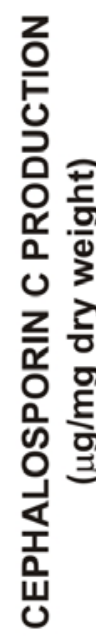

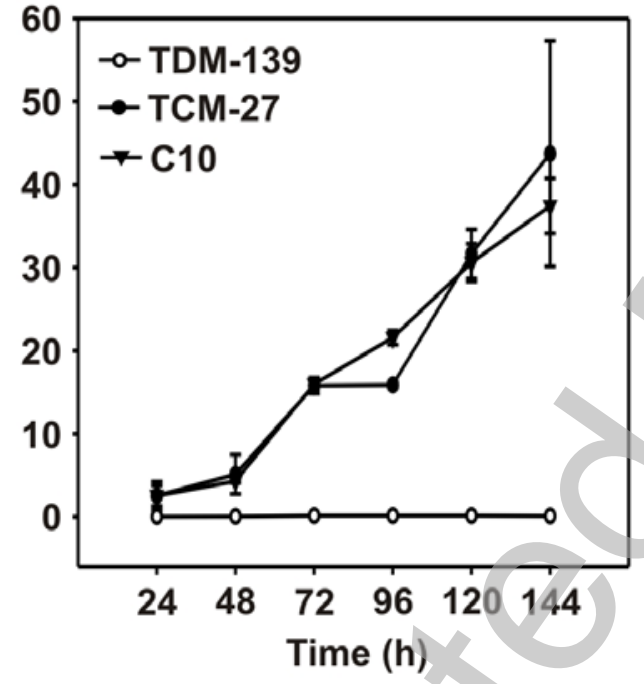

B

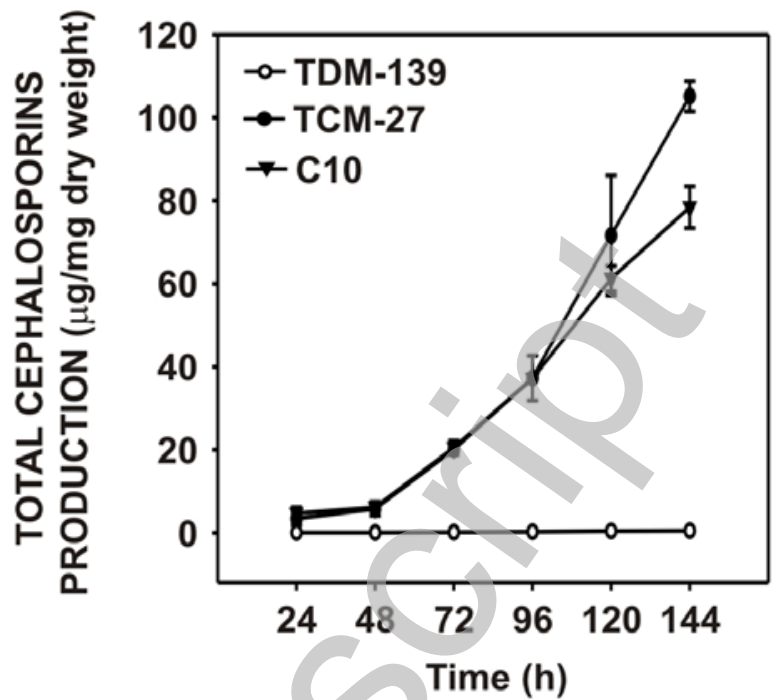

D

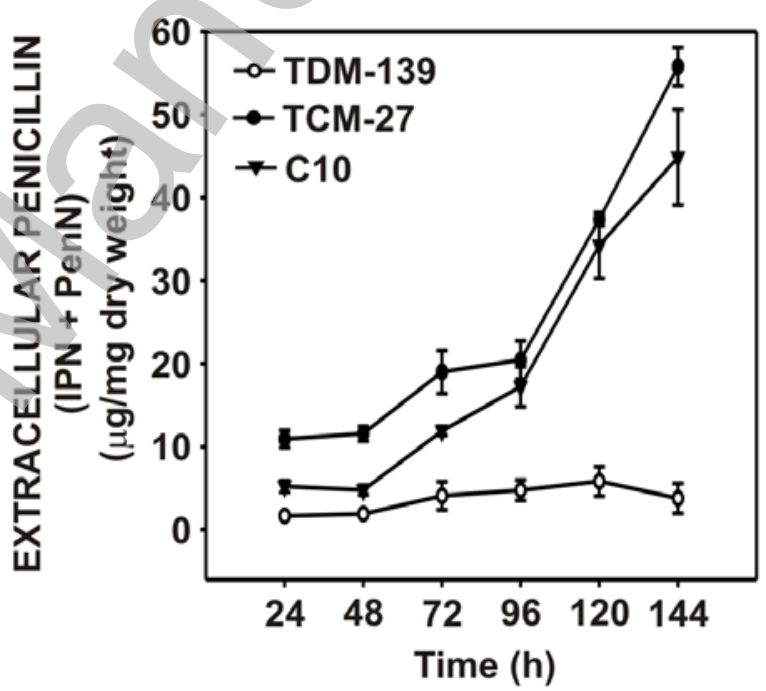

E

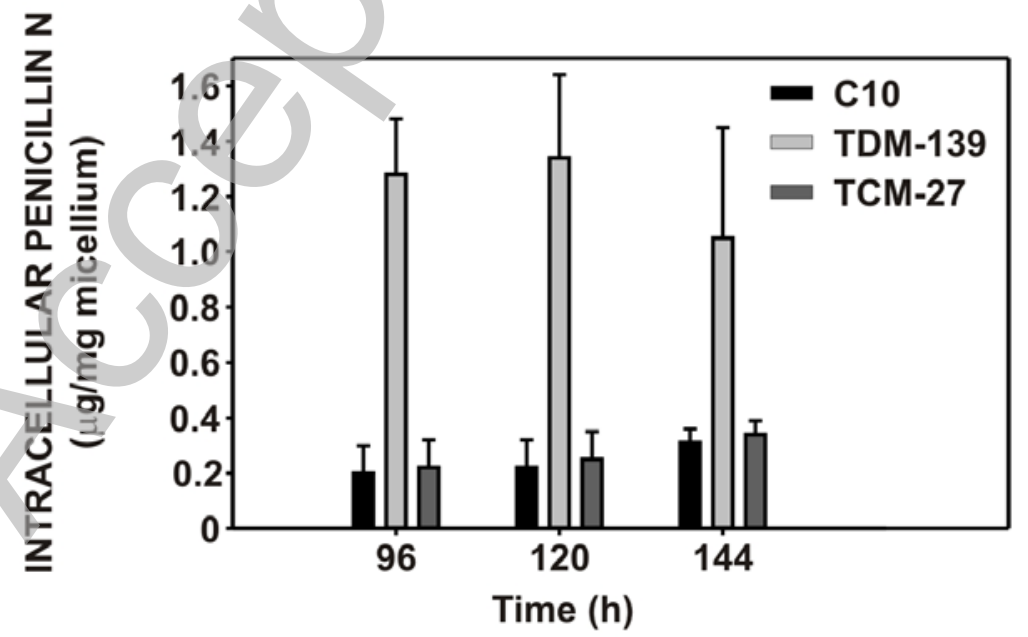

Figure 3. Teijeira et al. 
A

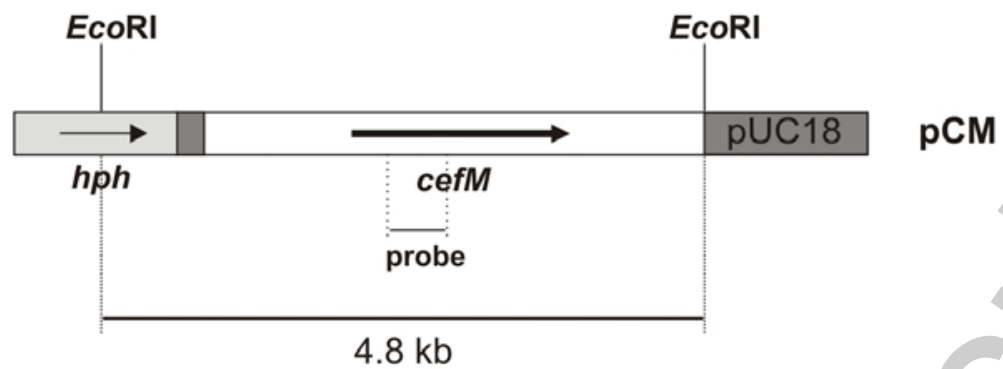

B

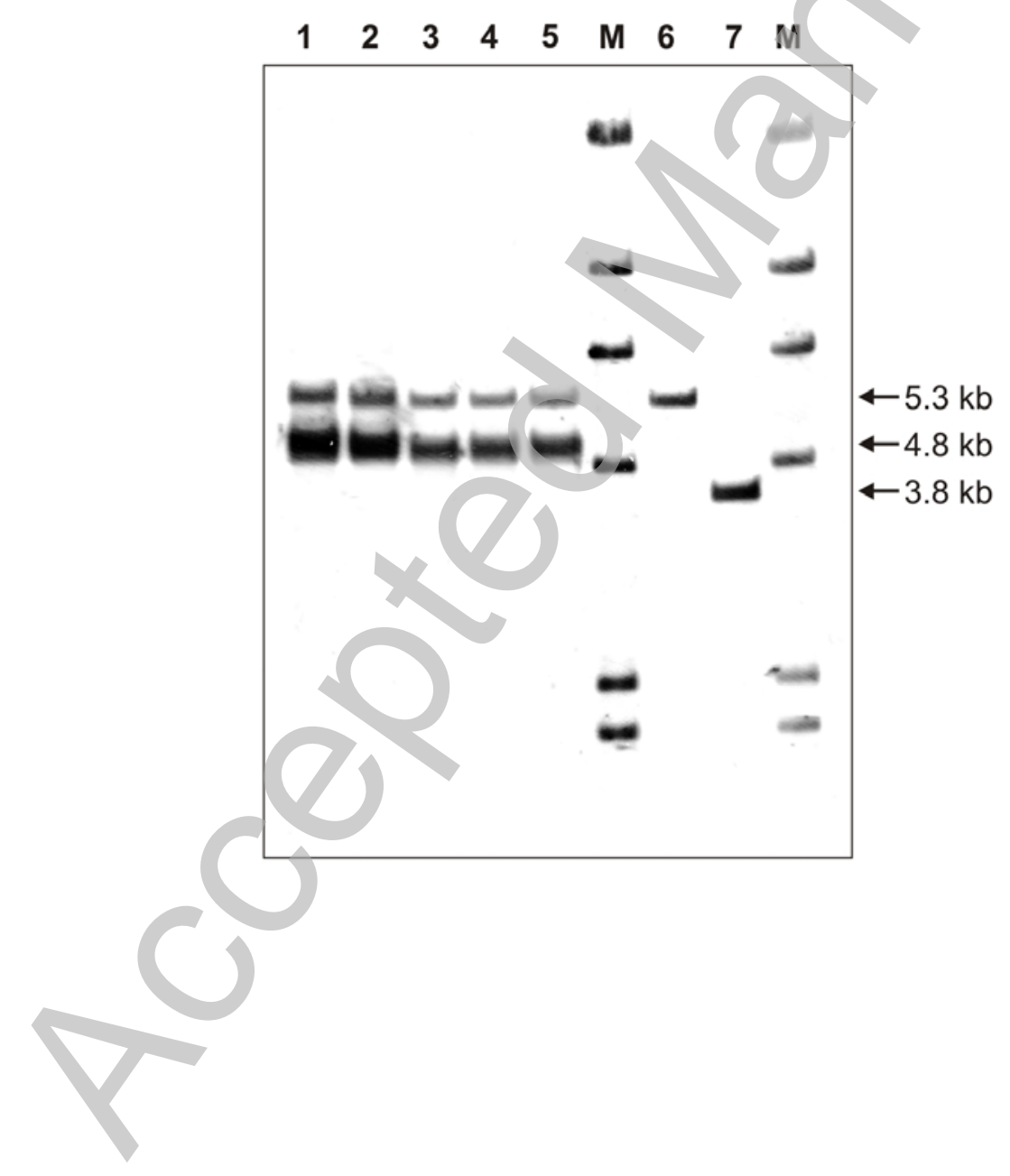

Figure 4. Teijeira et al. 
A

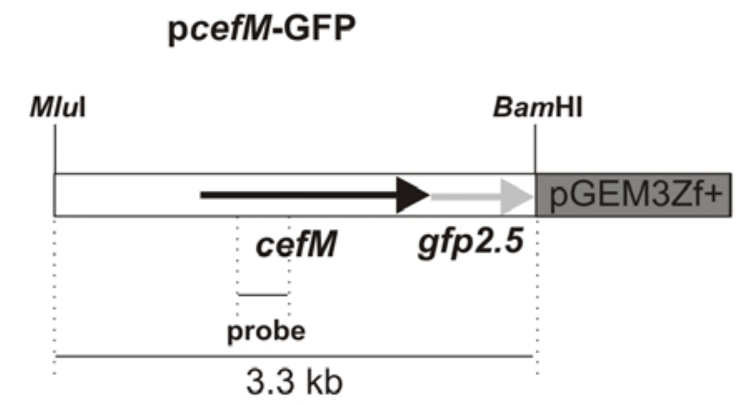

B
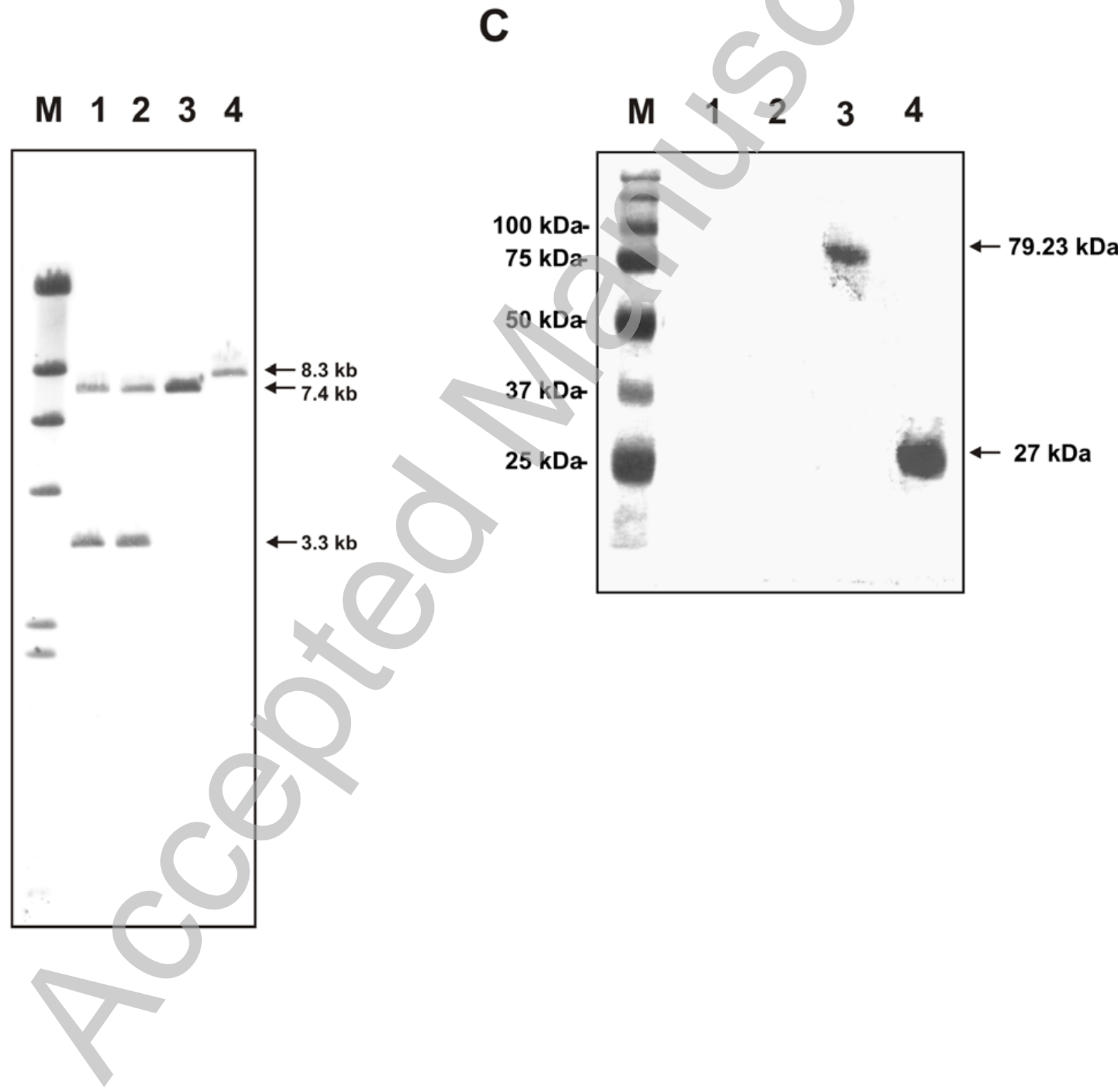

Figure 5. Teijeira et al.

Licenced copy. Copying is not permitted, except with prior permission and as allowed by law. (C) 2008 The Authors Journal compilation (C) 2008 Biochemical Society 
B Biochemical Journal Immediate Publication. Published on 08 Oct 2008 as manuscript BJ20081180

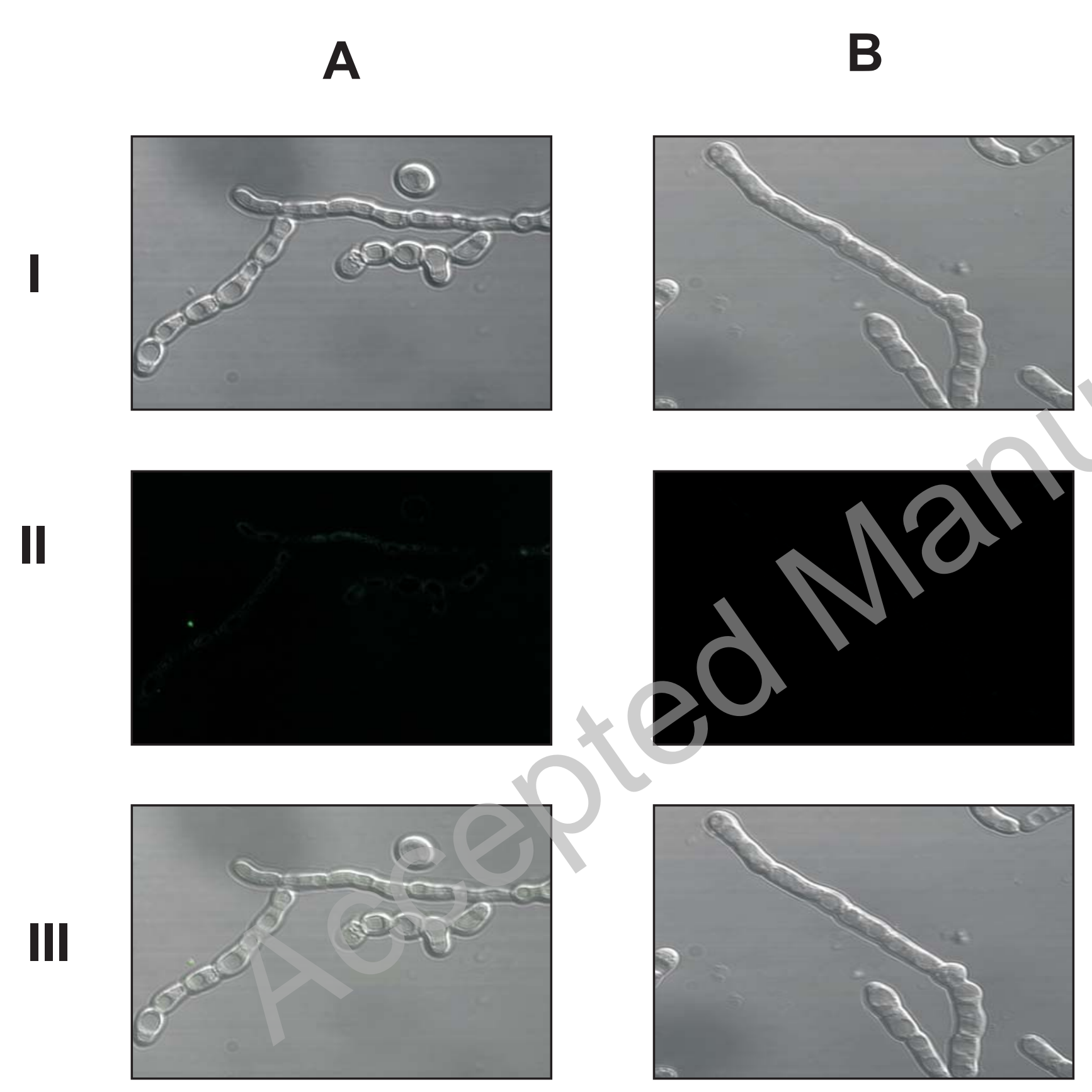

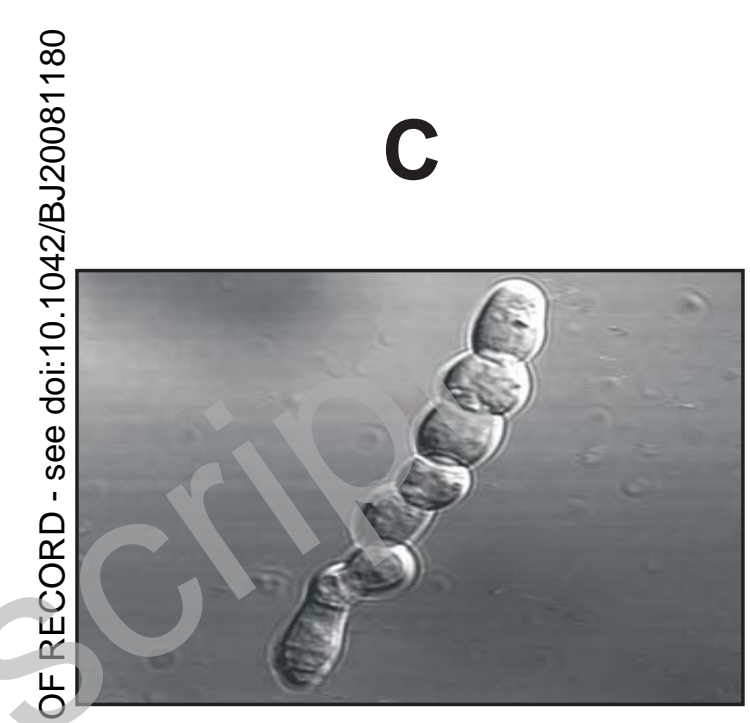
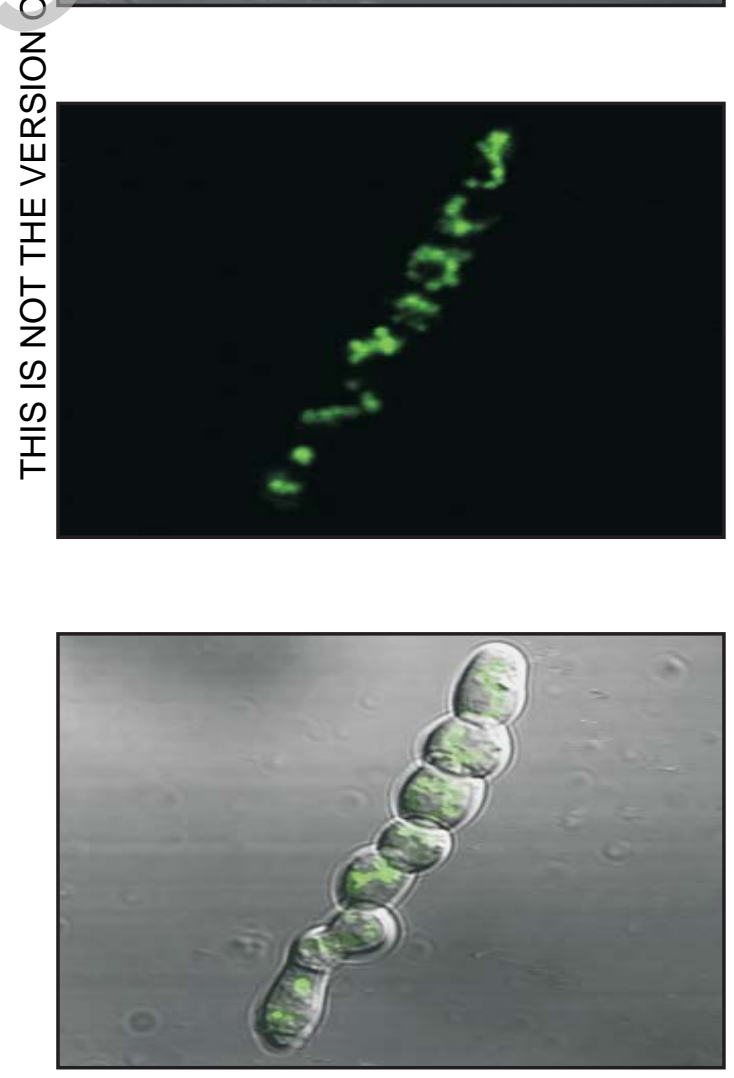

Figure 6. Teijeira et al. 
B Biochemical Journal Immediate Publication. Published on 08 Oct 2008 as manuscript BJ20081180 


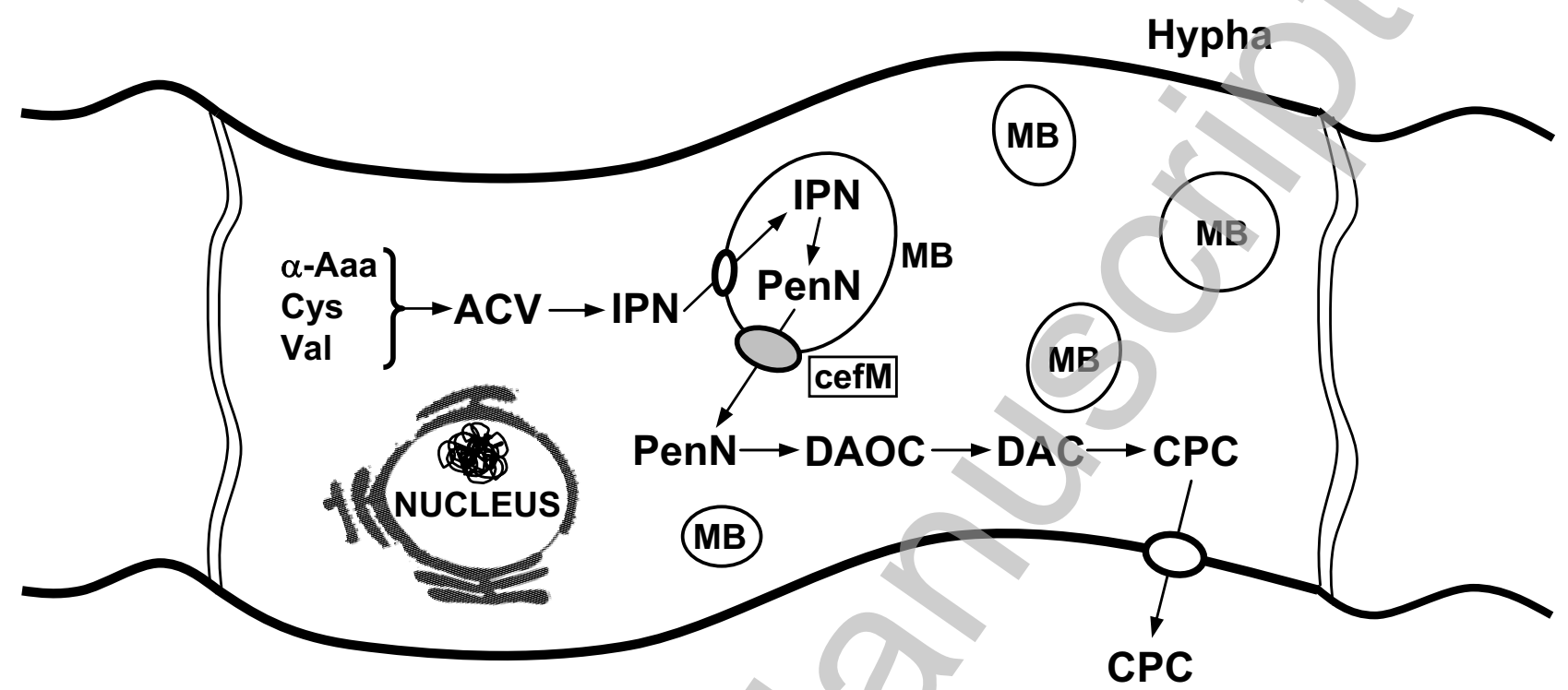

Figure 8. Teijeira et al. 